\title{
Group III Metabotropic Glutamate Receptors and Exocytosed Protons Inhibit L-Type Calcium Currents in Cones But Not in Rods
}

\author{
Nobutake Hosoi, Itaru Arai, and Masao Tachibana \\ Department of Psychology, Graduate School of Humanities and Sociology, The University of Tokyo, Tokyo 113-0033, Japan
}

\begin{abstract}
Light responses of photoreceptors (rods and cones) are transmitted to the second-order neurons (bipolar cells and horizontal cells) via glutamatergic synapses located in the outer plexiform layer of the retina. Although it has been well established that postsynaptic group III metabotropic glutamate receptors (mGluRs) of $\mathrm{ON}$ bipolar cells contribute to generating the $\mathrm{ON}$ signal, presynaptic roles of group III mGluRs remain to be elucidated at this synaptic connection. We addressed this issue by applying the slice patch-clamp technique to the newt retina. OFF bipolar cells and horizontal cells generate a steady inward current in the dark and a transient inward current at light offset, both of which are mediated via postsynaptic non-NMDA receptors. A group III mGluR-specific agonist, L-2-amino-4phosphonobutyric acid (L-AP-4), inhibited both the steady and off-transient inward currents but did not affect the glutamate-induced current in these postsynaptic neurons. L-AP-4 inhibited the presynaptic L-type calcium current $\left(I_{\mathrm{Ca}}\right)$ in cones by shifting the voltage dependence of activation to more positive membrane potentials. The inhibition of $I_{\mathrm{Ca}}$ was most prominent around the physiological range of cone membrane potentials. In contrast, L-AP-4 did not affect L-type $I_{\mathrm{Ca}}$ in rods. Paired recordings from photoreceptors and the synaptically connected second-order neurons confirmed that L-AP-4 inhibited both $I_{\mathrm{Ca}}$ and glutamate release in cones but not in rods. Furthermore, we found that exocytosed protons also inhibited $I_{\mathrm{Ca}}$ in cones but not in rods. Selective modulation of $I_{\mathrm{Ca}}$ in cones may help broaden the dynamic range of synaptic transfer by controlling the amount of transmitter release from cones.
\end{abstract}

Key words: group III metabotropic glutamate receptor; cone; rod; L-type calcium current; L-AP-4; proton feedback

\section{Introduction}

In the dark, photoreceptors continuously release glutamate in a calcium-dependent manner to their postsynaptic neurons (bipolar cells and horizontal cells) in the outer plexiform layer (OPL) of the retina (Dowling and Ripps, 1973; Copenhagen and Jahr, 1989; Schmitz and Witkovsky, 1996). During light stimulation, photoreceptors hyperpolarize and reduce glutamate release. ON and OFF bipolar cells express different types of glutamate receptors, thereby responding differently to the released glutamate. OFF bipolar cells and horizontal cells have non-NMDA receptors on their dendrites and are hyperpolarized when concentration of glutamate in the synaptic cleft is reduced during light stimulation (Maple et al., 1999; Thoreson and Witkovsky, 1999). In contrast, one of the group III metabotropic glutamate receptors (mGluRs), mGluR6, is negatively coupled to nonselective cation channels in

\footnotetext{
Received July 8, 2004; revised March 10, 2005; accepted March 11, 2005.

This work was supported by Grant-in-Aid for Scientific Research 12053212 and by the Special Coordination Funds for Promoting Science and Technology (The Neuroinformatics Research in Vision Project) from the Ministry of Education, Science, Sports and Culture to M.T. We thank Takeshi Sakaba for critical review of this manuscript and for valuable discussions and comments. We thank Jeongchul Hong for participation in early experiments.

Correspondence should be addressed to Masao Tachibana, Department of Psychology, Graduate School of Humanities and Sociology, The University of Tokyo, 7-3-1 Hongo, Bunkyo-ku, Tokyo 113-0033, Japan. E-mail: Ltmasao@L.u-tokyo.ac.jp.

N. Hosoi's present address: Department of Membrane Biophysics, Max-Planck Institute for Biophysical Chemistry, Am Fassberg, 37077 Göttingen, Germany.

DOI:10.1523/JNEUROSCI.2735-04.2005

Copyright $\odot 2005$ Society for Neuroscience $\quad$ 0270-6474/05/254062-11\$15.00/0
}

ON bipolar cells, and therefore, ON bipolar cells are depolarized by light stimulation (Nomura et al., 1994; Masu et al., 1995; Nawy, 1999; Thoreson and Witkovsky, 1999; Dhingra et al., 2000; Vardi et al., 2000).

In the OPL, group III mGluRs are expressed not only in postsynaptic ON bipolar cells but also in presynaptic photoreceptors (Brandstätter and Hack, 2001). Although the postsynaptic role of mGluR6 in generating the ON signal is well established (Shiells et al., 1981; Slaughter and Miller, 1981; Nawy and Jahr, 1990; Nakanishi, 1994), presynaptic roles of group III mGluRs are not well known. Koulen et al. (1999) have recently shown that another group III mGluR, mGluR8, is distributed in photoreceptor terminals in the rat retina and that activation of mGluR8 decreases the intracellular calcium concentrations in dissociated photoreceptors, although underlying mechanisms of the calcium regulation were not identified in their study. It has been reported that the group III mGluR-specific agonist L-2-amino-4phosphonobutyric acid (L-AP-4) not only blocks the ON signal but also reduces light responses of OFF bipolar cells and cone horizontal cells (Nawy et al., 1989; Hare and Owen, 1992; Higgs et al., 2002; Hirasawa et al., 2002). However, simultaneous activation of many different types of neurons in retinal circuits by light stimulation compromises interpretation of changes in photoresponses. Furthermore, it is not clear which type of photoreceptor (cone or rod) is modulated by mGluRs. Cone synapses have faster kinetics of transmission than rod synapses (Schnapf and Copen- 
hagen, 1982), and negative feedback through mGluRs may be one of the underlying mechanisms of faster kinetics of cone synapses.

In the present study, using a newt retinal slice preparation, we investigated presynaptic roles of group III mGluRs in glutamatergic synaptic transmission in the OPL and examined how L-AP-4 affected glutamate release from cones and rods by making paired recordings (Matsui et al., 1998; DeVries and Schwartz, 1999) to avoid possible network effects. We found that L-AP-4 reduced glutamate release from cones by inhibiting L-type calcium current $\left(I_{\mathrm{Ca}}\right)$ and that exocytosed protons also inhibited $I_{\mathrm{Ca}}$ in cones. In contrast, L-type $I_{\mathrm{Ca}}$ in rods was insensitive to L-AP-4 and exocytosed protons. These cone-specific modulations of $I_{\mathrm{Ca}}$ may have an important function in visual information processing in a light-adapted state.

\section{Materials and Methods}

Retinal slices of adult newts (Cynops pyrrhogaster) were prepared as described previously (Matsui et al., 1998). Briefly, the anterior chamber of the enucleated eye was removed, and the ganglion cell layer side of the retina was attached to a piece of filter paper. After removing the sclera, the filter paper and the retina were sliced together into $190 \mu \mathrm{m}$ sections with a razor blade. These procedures were done within $20 \mathrm{~min}$ after decapitation under room light, in accordance with A Manual for the Conduct of Animal Experiments in The University of Tokyo and Guiding Principles for the Care and Use of Animals in the Field of Physiological Sciences, The Physiological Society of Japan. The retinal slices were set in a chamber on the stage of a microscope (Standard; Zeiss, Oberkochen, Germany) equipped with infrared (IR) illumination and an IR-sensitive camera (C2400-07ER; Hamamatsu Photonics, Hamamatsu, Japan) in a light-tight Faraday cage. All experiments were performed under room light. Light-evoked responses were well preserved in all cell types except photoreceptors, which ran down 3-5 min after establishment of the whole-cell configuration.

The slices were superfused continuously with oxygenated amphibian saline composed of the following (in $\mathrm{mm}$ ): $110 \mathrm{NaCl}, 2 \mathrm{KCl}, 2 \mathrm{CaCl}_{2}, 1$ $\mathrm{MgCl}_{2}, 5$ glucose, and 5 HEPES (titrated to $\mathrm{pH} 7.8$ with $\mathrm{NaOH}$ ). The control saline also contained picrotoxin $(200 \mu \mathrm{M})$ and strychnine (10 $\mu \mathrm{M})$ to block GABA and glycine receptors and D-2-amino-5phosphonopentanoic acid (D-AP-5; $50 \mu \mathrm{M})$ to block NMDA receptors, with which L-AP-4 may interact (Contractor et al., 1998). D-Tubocurarine $(60 \mu \mathrm{M})$ and atropine $(2 \mu \mathrm{M})$ were sometimes added. Because the obtained results were similar regardless of the cholinergic antagonists, data were pooled together. In some experiments, we used a bicarbonate-buffered saline, in which $5 \mathrm{~mm}$ HEPES and $15 \mathrm{~mm} \mathrm{NaCl}$ in the amphibian saline were replaced with $25 \mathrm{~mm}$ bicarbonate, and the $\mathrm{pH}$ was adjusted to 7.8 with $5 \% \mathrm{CO}_{2} / 95 \% \mathrm{O}_{2}$. For experiments to increase the buffering capacity of the extracellular $\mathrm{pH}$, the amphibian saline was modified by raising HEPES to $40 \mathrm{~mm}$, lowering $\mathrm{NaCl}$ to $70 \mathrm{~mm}$, and adding tetraethylammonium (TEA)-Cl $(30 \mathrm{~mm})$. Pharmacological agents dissolved in extracellular solutions were bath applied or pressure applied from a puff pipette. Picrotoxin, strychnine, D-tubocurarine, atropine, and nifedipine were purchased from Sigma (St. Louis, MO). D-AP-5, 2,3-dioxo-6-nitro-1,2,3,4-tetrahydrobenzo[f] quinoxaline-7sulfonamide (NBQX), L-AP-4, (2S)-2-amino-2-[(1S,2S)-2-carboxycycloprop-1-yl]-3-(xanth-9-yl) propanoic acid (LY341495), (RS)- $\alpha$ cyclopropyl-4-phosphonophenylglycine (CPPG), and (RS)- $\alpha$-methyl-4phosphonophenylglycine (MPPG) were from Tocris Cookson (Bristol, UK). Exogenously expressed group III mGluRs are activated by L-AP-4 in the range of a few micromolar (mGluR4,6,8) to hundreds of micromoles per liter (mGluR7) (Conn and Pin, 1997). We often used relatively high concentrations of L-AP-4 $(100-200 \mu \mathrm{M})$ to ensure that L-AP-4 could activate all possible subtypes of group III mGluRs. However, it was difficult to estimate the effective concentration of L-AP-4 precisely, because L-AP-4 was often pressure applied from a puff pipette to facilitate the washout before rundown. LY341495, CPPG, and MPPG were dissolved in $\mathrm{NaOH}$ and stored as concentrated stock solutions. Picrotoxin, nifedipine, and NBQX were prepared as concentrated stock solutions in di- methyl sulfoxide. The final concentration of dimethyl sulfoxide after dilution was always kept $<0.08 \%(\mathrm{v} / \mathrm{v})$.

Patch pipettes for whole-cell recordings had resistances of 6-10 $\mathrm{M} \Omega$ in the control solution. The recording pipette for bipolar cells and horizontal cells contained the following (in mM): $84 \mathrm{CsCH}_{3} \mathrm{SO}_{4}, 4 \mathrm{CsCl}, 10$ TEA$\mathrm{Cl}$, $5.5 \mathrm{MgCl}_{2}, 0.2$ BAPTA, 20 HEPES, 5 ATP disodium salt, 0.5 GTP trisodium salt, and $0.25 \%$ Lucifer yellow dipotassium salt, $\mathrm{pH} 7.7-7.8$ with $\mathrm{CsOH}$. For recordings of $I_{\mathrm{Ca}}$ from photoreceptors, the pipette contained the following (in $\mathrm{mM}$ ): $72-77 \mathrm{CsCH}_{3} \mathrm{SO}_{4}, 4$ Cs-glutamate, $10 \mathrm{CsCl}$, 10 TEA-Cl, $2 \mathrm{MgCl}_{2}$, 5 EGTA, $0.5 \mathrm{CaCl}_{2}$, 20 HEPES, 1-5 ATP disodium salt, $0.1-0.5$ GTP trisodium salt, and $0.25 \%$ Lucifer yellow dipotassium salt, $\mathrm{pH} 7.7-7.8$ with $\mathrm{CsOH}$. In some experiments, GTP was replaced with guanosine $5^{\prime}$-[ $\beta$-thio]diphosphate $(\mathrm{GDP} \beta S)$. For current-clamp recordings from cones, the pipette solution contained the following (in mM): 79 K-gluconate, $20 \mathrm{KCl}, 2 \mathrm{MgCl}_{2}, 5 \mathrm{EGTA}, 0.5 \mathrm{CaCl}_{2}, 20 \mathrm{HEPES}, 1$ ATP disodium salt, 0.1 GTP trisodium salt, and $0.1 \%$ Lucifer yellow dipotassium salt, $\mathrm{pH}$ 7.7-7.8 with $\mathrm{KOH}$. Liquid junction potentials were corrected for all recordings.

Photoreceptors and second-order neurons (OFF bipolar cells and horizontal cells) were whole-cell clamped with two EPC-7 patch-clamp amplifiers (List Biologic, Darmstadt, Germany). Current and voltage records were low-pass filtered at $1-10 \mathrm{kHz}$ and digitized at $5-25 \mathrm{kHz}$ with a digitizer board (Digidata 1200A; Axon Instruments, Union City, CA), and data acquisition was performed by pClamp software (Axon Instruments). Unless otherwise noted, the on-line $\mathrm{P} / \mathrm{N}$ leak subtraction proto$\operatorname{col}(n=4)$ was enabled. The series resistance was $10-40 \mathrm{M} \Omega$ and was compensated by $10-40 \%$.

The ambient light intensity was 238 lux at the position of retinal slices on the microscope stage. A full-field white light (308-568 lux) was applied to the retinal slices through the microscope condenser. Cell types were identified by their light-evoked responses and morphology, which was visualized by Lucifer yellow staining after recordings. OFF bipolar cells have a Landolt club and an axon extending to the sublamina a in the inner plexiform layer and thus could be distinguished from horizontal cells, which have somas in the distal border of the inner nuclear layer and extend their processes only to the OPL. Dye coupling between horizontal cells was not observed in the present study. Cones and rods were readily identified by their characteristic morphology (see Figs. $2 \mathrm{~A}, 6 \mathrm{~A}$ ) and light responses (Nakatani and Yau, 1988).

Pooled data were expressed as mean \pm SEM. Statistical significance was assessed by two-tailed, paired or unpaired Student's $t$ tests. Differences were considered significant if $p<0.05$. Voltage dependence of $I_{\mathrm{Ca}}$ in photoreceptors was quantified by fitting a sigmoid curve to the increasing portion of the $I-V$ relationship, using the function $I_{\mathrm{Ca}}(V)=$ $I_{\max } /\left(1+\exp \left[\left(V-V_{\text {half }}\right) / V_{\text {slope }}\right]\right)$, where $I_{\mathrm{Ca}}(V)$ is $I_{\mathrm{Ca}}$ at voltage $V, I_{\max }$ is the maximum current, $V_{\text {half }}$ is the voltage for half activation, and $V_{\text {slope }}$ is a constant (Corey et al., 1984; Rieke and Schwartz, 1994).

\section{Results}

\section{$\mathrm{L}-\mathrm{AP}-4$ reduced glutamatergic synaptic inputs to the} second-order neurons

We first examined whether activation of group III mGluRs affected light responses of the second-order neurons (OFF bipolar cells and horizontal cells) in the newt retinal slice preparation. To focus on the presynaptic roles of group III mGluRs, we recorded postsynaptic responses from OFF bipolar cells and horizontal cells but not from ON bipolar cells with postsynaptic mGluR6. Possible inhibitory inputs by GABA and glycine were blocked with picrotoxin $(200 \mu \mathrm{M})$ and strychnine $(10 \mu \mathrm{M})$.

In the absence of light stimulation, OFF bipolar cells (voltage clamped between -72 and $-85 \mathrm{mV}$ ) showed a steady inward current (a dark current). During light stimulation, the dark current was reduced in amplitude (Fig. $1 \mathrm{~A}$, Control). After the cessation of light stimulation, a transient inward current (an OFF undershoot) was evoked. These photoresponses are similar to those reported previously (Maple et al., 1999; Wu et al., 2000; Higgs and Lukasiewicz, 2002), and it has been shown that these 

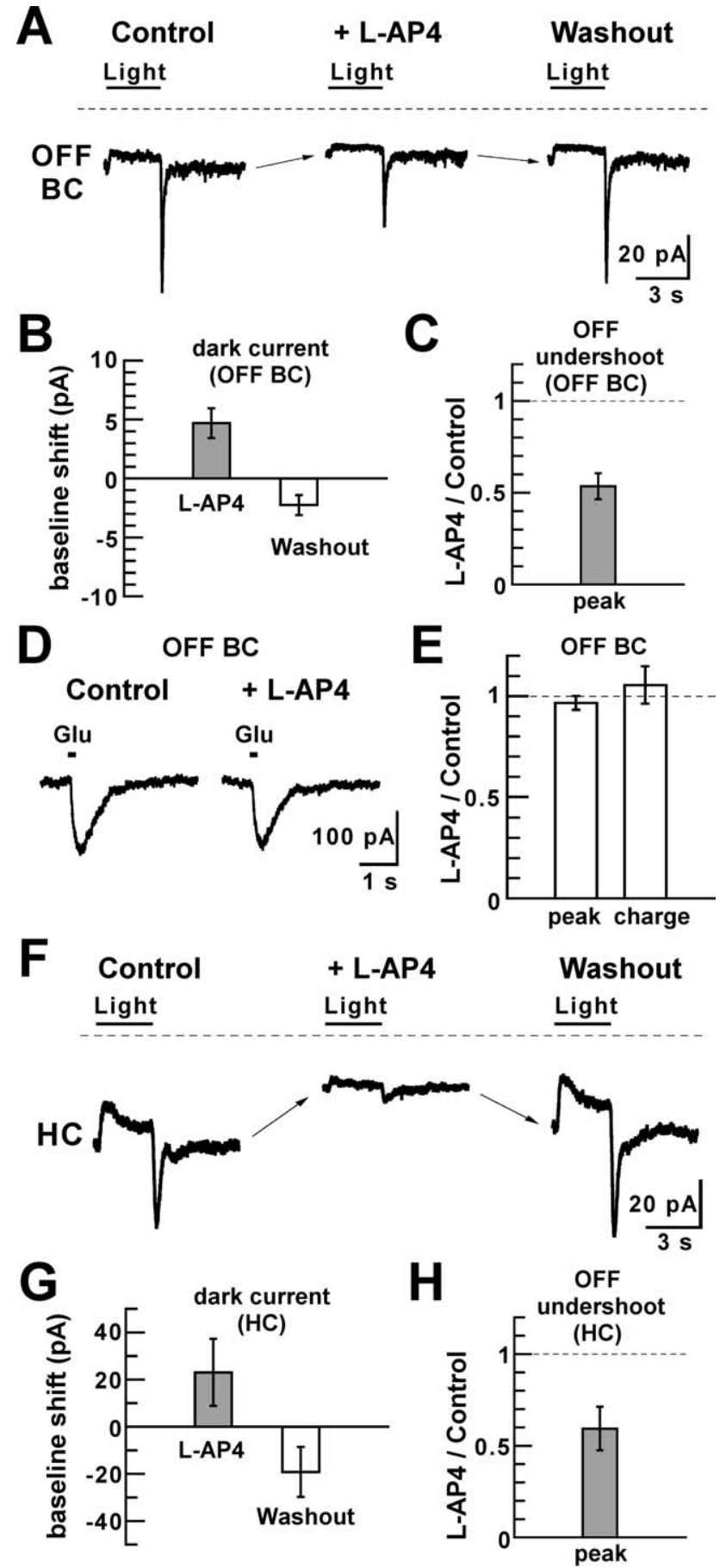

Figure 1. Effects of L-AP-4 on light responses of retinal second-order neurons. A, An OFF bipolar cell (OFF BC) was voltage clamped at $-85 \mathrm{mV}$, and a full-field white light stimulus was applied for $3 \mathrm{~s}$ (left, Control). A broken line indicates a zero current level. L-AP-4 (100 $\mu \mathrm{M})$ was puff applied continuously to activate group III mGluRs (middle, +L-AP-4). After washout of L-AP-4, the response recovered (right, Washout). Arrows indicate the shift of the dark current (baseline shift) from the preceding condition. B, Pooled data of the baseline shift in OFF bipolar cells. Positive values indicate a decrease in the dark current. $C$, Pooled data of the OFF undershoot in OFF bipolar cells. Peak amplitude of the OFF undershoot was measured from the averaged current during the last $100 \mathrm{~ms}$ before the light offset. Values were normalized to control. D, No effect of L-AP-4 $(100 \mu \mathrm{m})$ on the glutamate-induced responses in an OFF bipolar cell voltage clamped at $-85 \mathrm{mV}$. Glutamate $(200 \mu \mathrm{m})$ was puff applied for $100 \mathrm{~ms}$ (bar) in the $\mathrm{Co}^{2+}(3 \mathrm{~mm})$ solution. E, Pooled data of the peak amplitude and total charge of the glutamateinduced responses in OFF bipolar cells $(n=5)$. Values were normalized to control. $\boldsymbol{F}$, A horizontal cell (HC) was voltage clamped at $-86 \mathrm{mV}$, and the same experiments were performed as in A. $\mathbf{G}, \boldsymbol{H}$, Pooled data of the baseline shift and the $0 \mathrm{FF}$ undershoot in horizontal cells, respectively. Bar graphs in this and subsequent figures indicate mean \pm SEM. currents are mediated by non-NMDA receptors (Slaughter and Miller, 1983; Gilbertson et al., 1991; Wu and Maple, 1998; Maple et al., 1999). Application of the group III mGluR-selective agonist L-AP-4 $(100 \mu \mathrm{M})$ reduced both the amplitude of the dark current (Fig. 1A, + L-AP-4, arrow) and the OFF undershoot (Fig. 1A, +L-AP-4). The effects of L-AP-4 were reversible (Fig. $1 A$, Washout). On average, reduction of the dark current by L-AP-4 (Fig. $1 B$ ) (baseline shift, $+4.7 \pm 1.3 \mathrm{pA} ; n=22 ; p<0.01$ ) and its recovery after washout (Fig. $1 B$ ) (baseline shift, $-2.3 \pm 0.8 \mathrm{pA}$; $n=18 ; p<0.05)$ were statistically significant. L-AP-4 also reduced the peak amplitude of the OFF undershoot significantly (Fig. 1C) $(0.53 \pm 0.07$ of control; $n=26 ; p<0.01)$.

To exclude possible postsynaptic effects of L-AP-4, we next examined the glutamate-induced responses in OFF bipolar cells. Synaptic inputs to OFF bipolar cells were blocked by replacing divalent cations of the control solution with $3 \mathrm{mM} \mathrm{Co}^{2+}$. Indeed, $\mathrm{Co}^{2+}$ abolished the dark currents and the photoresponses. Puff application of glutamate $(200 \mu \mathrm{M})$ to OFF bipolar cell dendrites induced an inward current (Fig. $1 D$, Control), which could be blocked by NBQX, a blocker of non-NMDA receptors $(n=3)$ (data not shown). L-AP-4 (100 $\mu \mathrm{M})$ had no significant effect on the peak amplitude or total charge (i.e., the time integral) of the glutamate-induced currents (Fig. $1 D,+\mathrm{L}-\mathrm{AP}-4, E$ ) (peak amplitude, $0.97 \pm 0.03$ of control; total charge, $1.06 \pm 0.09$ of control; $n=5)$.

Horizontal cells also receive glutamatergic synaptic inputs from photoreceptors. L-AP-4 (100 $\mu \mathrm{M})$ reversibly reduced both the dark current (Fig. $1 F, G$ ) (baseline shift by L-AP-4, $+23.06 \pm$ $14.22 \mathrm{pA} ; n=5$, restoration of the dark current by washout, $-19.18 \pm 10.60 \mathrm{pA} ; n=3$ ) and the OFF undershoot (Fig. $1 F, H$ ) (peak amplitude, $0.59 \pm 0.12$ of control; $n=5 ; p<0.05$ ) in horizontal cells voltage clamped at $-85 \mathrm{mV}$. These currents were blocked by NBQX $(20 \mu \mathrm{M}), \mathrm{Co}^{2+}(3 \mathrm{mM})$, or $\mathrm{Cd}^{2+}(50 \mu \mathrm{M})$, indicating that these currents are non-NMDA receptor-mediated postsynaptic currents. In $\mathrm{Co}^{2+}$ solution, $\mathrm{L}-\mathrm{AP}-4(100 \mu \mathrm{M})$ did not affect glutamate $(200 \mu \mathrm{M})$-induced currents of horizontal cells (peak amplitude, $0.94 \pm 0.02$ of control; total charge, $1.08 \pm$ $0.03 ; n=4)$.

Because GABAergic inhibitory synaptic transmission in the OPL had been blocked by picrotoxin, it is likely that activation of presynaptic group III mGluRs inhibited glutamate release from photoreceptors, thereby reducing the dark current and the OFF undershoot in OFF bipolar cells and horizontal cells. All the experiments in the present study were performed under room light, and thus the light responses in the second-order neurons (Fig. 1) may be evoked in a relatively cone-preferring condition.

\section{L-AP-4 inhibited L-type $I_{\mathrm{Ca}}$ in cones}

It has been shown that activation of mGluRs by L-AP-4 reduces presynaptic $I_{\mathrm{Ca}}$ and transmitter release in the CNS synapses (Takahashi et al., 1996; Wu and Saggau, 1997). To test the possibility that L-AP-4 can inhibit glutamate release from photoreceptors by suppressing presynaptic $I_{\mathrm{Ca}}$, we measured $I_{\mathrm{Ca}}$ directly from cones (Fig. 2A).

A cone was voltage clamped at $-50 \mathrm{mV}$, and a $50 \mathrm{~ms}$ depolarizing pulse to $-20 \mathrm{mV}$ produced a sustained inward current (Fig. $2 B$, left, Control, thin trace). L-AP-4 (100-200 $\mu \mathrm{M})$ slowed down activation kinetics of the current and reduced its peak amplitude (Fig. 2 B, left, $+\mathrm{L}$-AP-4, thick trace). These effects were reversible after washout (Fig. $2 B$, right, Washout, thin trace). We confirmed that this inward current was the L-type $I_{\mathrm{Ca}}$, because it was abolished by nifedipine (10-20 $\mu \mathrm{M}$ ) (Fig. $2 \mathrm{~B}$, right, +Nifedipine, thick trace), consistent with previous studies (Barnes and Hille, 


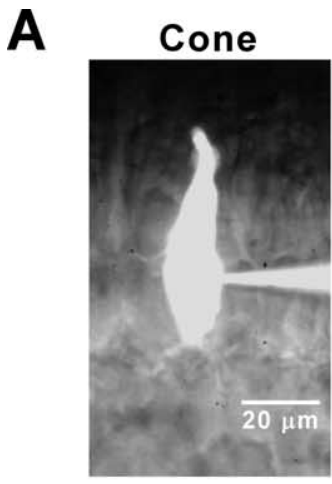

B

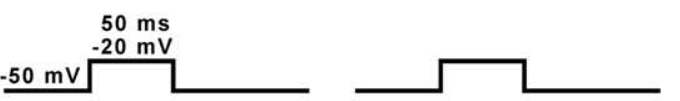

C
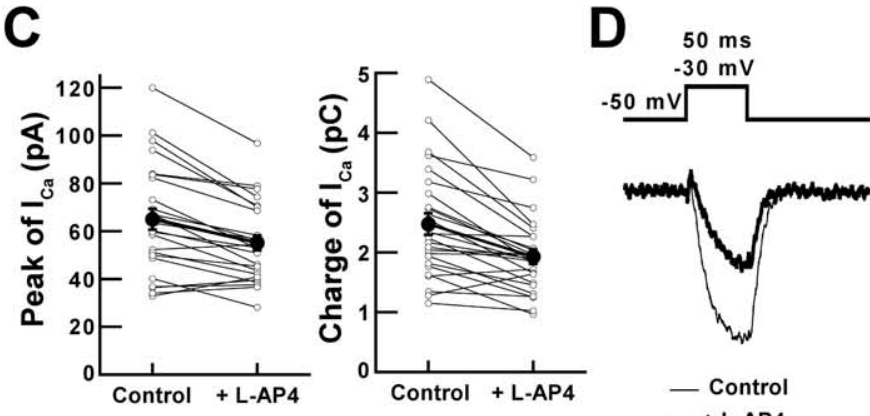

- Washout

$$
\text { - Control }
$$$$
\text { - + L-AP4 }
$$

- + Nifedipine

$\mathbf{E}$

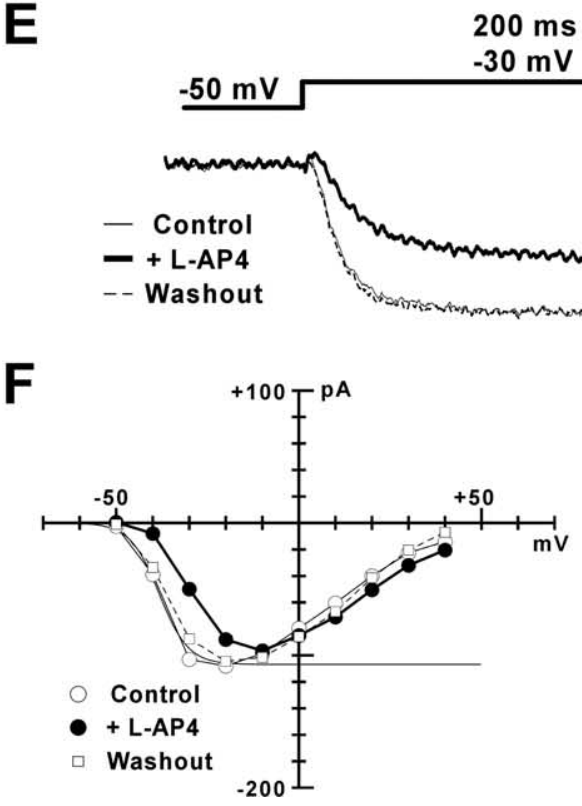

$200 \mathrm{~ms}$
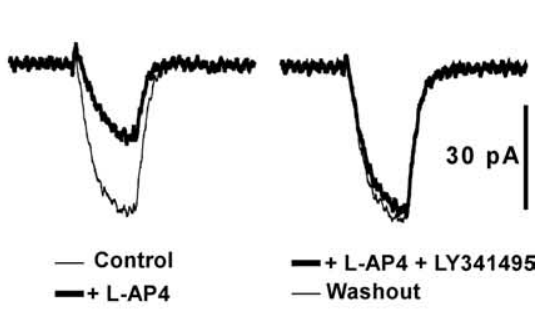

-Washout

$\mathbf{G}$
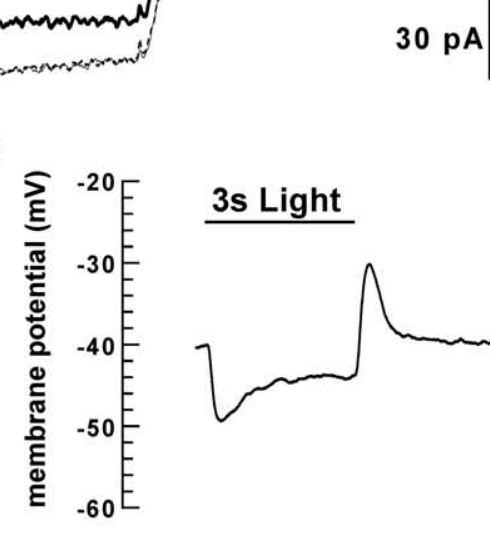

Figure 2. Effects of L-AP-4 on the cone L-type $I_{C a} \cdot A$, Fluorescent image of a cone stained with Lucifer yellow. $\boldsymbol{B}$, Inward currents were evoked by $50 \mathrm{~ms}$ depolarizing pulses from -50 to $-20 \mathrm{mV}$. Left, Currents in the absence (thin trace) and presence (thick trace) of L-AP-4 (200 $\mu \mathrm{M})$. Right, The current after washout of L-AP-4 (thin trace) and the current in the presence of nifedipine (10 $\mu \mathrm{M})$ (thick trace). $C$, Effects of $\mathrm{L}-\mathrm{AP}-4$ on the peak amplitude (left) and total charge (right) of $\mathrm{C}_{\mathrm{Ca}}$ (the nifedipine-sensitive current). Filled circles indicate mean values from 26 cells. Individual data points are shown as open circles. D, Suppression of L-AP-4 induced inhibition by group II and III mGluR antagonist LY341495. After confirming the inhibitory effect of L-AP-4 (50 $\mu \mathrm{M})$ on the cone I Ca $_{\text {(left), }}$ LY341495 (30 $\mu \mathrm{M})$ and L-AP-4 were coapplied (right). $E$, Effects of L-AP-4 on the cone $I_{C \mathrm{C}}$ elicited by a long pulse ( $\left.200 \mathrm{~ms}\right)$ from -50 to $-30 \mathrm{mV}$. $\boldsymbol{F}$, Effects of $\mathrm{L}-\mathrm{AP}-4$ on the $I_{\mathrm{Ca}}-V$ relationship. P/N leak subtraction was not used. $I_{\mathrm{Ca}_{\mathrm{a}}}$ amplitude was measured at the end of each pulse and plotted against the corresponding membrane potential. A sigmoid curve (thin line) was fitted to the increasing portion of the $I_{\text {Ca }}-V$ relationship. Fitted parameters of $I_{\text {max }} V_{\text {half }}$ and $V_{\text {slope }}$ to control were $-106.8 \mathrm{pA},-38.3 \mathrm{mV}$, and $-4 \mathrm{mV}$, respectively. G, Atypical light-evoked response recorded from the cone under current clamp. Four traces were averaged.

1989; Rieke and Schwartz, 1994; Wilkinson and Barnes, 1996; Schmitz and Witkovsky, 1997). Figure $2 C$ shows the peak amplitude (left) and total charge (right) of the cone $I_{\mathrm{Ca}}$ before (Control $)$ and after $(+\mathrm{L}-\mathrm{AP}-4)$ application of $\mathrm{L}-\mathrm{AP}-4$. Here, we defined the nifedipine-sensitive current as $I_{\mathrm{Ca}}$. On average, L-AP-4 re-

duced the peak amplitude from $64.99 \pm$ 4.39 to $55.16 \pm 3.16 \mathrm{pA}(n=26 ; p<0.01)$ and the total charge from $2.47 \pm 0.18$ to $1.93 \pm 0.12 \mathrm{pC}(n=26 ; p<0.01)$. L-AP-4 also prolonged the activation time constant of $I_{\mathrm{Ca}}$ from $4.52 \pm 0.55$ to $9.88 \pm 1.68$ $\mathrm{ms}(n=26 ; p<0.01)$.

We next tested the effects of mGluR antagonists in the newt retina. LY341495 (30 $\mu \mathrm{M}$ ) (Wright et al., 2000; Alapakkam et al., 2004; Kogo et al., 2004) could suppress the inhibitory effect of L-AP-4 $(50 \mu \mathrm{M})$ on the cone $I_{\mathrm{Ca}}$ (Fig. $\left.2 D\right)(n=5)$. This confirms that the effect of L-AP-4 is mediated by activation of group III mGluRs. We also examined whether the light responses of OFF bipolar cells were affected by LY341495 (30 $\mu \mathrm{M})$. LY341495 reversibly increased the peak amplitude of the OFF undershoot ( $1.34 \pm 0.02$ of control; $n=3$; $p<0.01$ ), although this antagonist did not have a prominent effect on the amplitude of the dark currents (baseline shift, $-0.80 \pm 0.56 \mathrm{pA} ; n=3 ; p=0.29$ ) (supplemental figure, available at www.jneurosci.org as supplemental material). This result suggests that glutamate released from photoreceptors at the cessation of light stimulation may be reduced quickly via activation of presynaptic mGluRs, resulting in the decrease of the OFF undershoot in OFF bipolar cells. However, the effects of LY341495 cannot be ascribed solely to group III mGluRs in photoreceptor terminals, because LY341495 is an antagonist of both group II and group III mGluRs (Kingston et al., 1998; Wright et al., 2000; Kogo et al., 2004). Surprisingly, CPPG $(300 \mu \mathrm{M})$, known as a group III mGluR antagonist (Jane et al., 1996; von Gersdorff et al., 1997; Awatramani and Slaughter, 2001; Nawy, 2004), could not suppress the inhibitory effect of L-AP-4 $(20-200 \mu \mathrm{M})$ on the cone $I_{\mathrm{Ca}}(n=4)$. MPPG (300 $\mu \mathrm{M})$, another group III mGluR antagonist (Jane et al., 1995; Koulen et al., 1999), was also ineffective in antagonizing L-AP-4-induced outward current in $\mathrm{ON}$ bipolar cells of the newt retina (data not shown). Group III mGluRs in newt retinas seem to have different pharmacological characteristics. Indeed, similar ineffectiveness of group III mGluR antagonists such as CPPG and $(S)$ 2-amino-2-methyl-4-phosphonobutanoic acid has been reported in the tiger salamander retina (Thoreson et al., 1997; Higgs et al., 2002).

We also examined the effect of L-AP-4 on the cone $I_{\mathrm{Ca}}$ elicited by a long pulse $(200 \mathrm{~ms})$. L-AP-4 reversibly reduced the initial activating current to a larger extent than the steady current $(20$ ms, $0.49 \pm 0.07$ of control, $p<0.05 ; 200 \mathrm{~ms}, 0.65 \pm 0.02$ of control, $p<0.05 ; n=3$ ) (Fig. $2 E$ ). This may partly explain why 
L-AP-4 suppressed the OFF undershoot more prominently than the dark current in second-order neurons (Fig. 1).

Figure $2 F$ shows the effect of L-AP-4 $(200 \mu \mathrm{M})$ on the $I-V$ relationship of the cone $I_{\mathrm{Ca}}$. In control, $I_{\mathrm{Ca}}$ was activated when the membrane potential was more positive than $-50 \mathrm{mV}$ (Fig. $2 F$, Control, open circles) and half activated at $-34.23 \pm 0.44 \mathrm{mV}$ ( $V_{\text {half }} ; n=18$ ). Application of L-AP-4 reversibly shifted the $I_{\mathrm{Ca}}-V$ relationship to more positive potentials (Fig. $2 \mathrm{~F}$, closed circles, +L-AP-4; open squares, Washout). Specifically, L-AP-4 shifted $V_{\text {half }}$ by $+4.02 \pm 0.61 \mathrm{mV}(n=12)$. Inhibition of $I_{\mathrm{Ca}}$ by L-AP-4 was most prominent between -50 and $-20 \mathrm{mV}$.

To learn the physiological range of the cone membrane potential, we recorded light responses from cones under currentclamp mode (Fig. 2G). Resting potential ranged between -40 and $-30 \mathrm{mV}$, light stimulation hyperpolarized the cones by $\sim 10$ $\mathrm{mV}$, and cessation of the light generated a transient depolarization up to $-30 \mathrm{mV}(n=3)$. Although the voltage range of photoresponses in cones may vary depending on the condition of light adaptation, the observed responses were comparable with previous observations (Hirasawa and Kaneko, 2003; Thoreson et al., 2003). Thus, the working range of newt cones (between -30 and $-50 \mathrm{mV}$ ) overlapped with the voltage range in which L-AP-4 inhibited $I_{\mathrm{Ca}}$ most effectively.

\section{L-AP-4 inhibited synaptic transmission from cones to the} second-order neurons

Most OFF bipolar cells and horizontal cells in amphibian retinas receive mixed synaptic inputs from both rods and cones (Lasansky, 1973, 1978; Yang and Wu, 1996, 1997; Wu et al., 2000). To isolate the effects of L-AP-4 on synaptic transmission from a single cone, we performed simultaneous whole-cell recordings from the synaptically connected pair of a cone and a second-order neuron (OFF bipolar cell or horizontal cell).

During depolarization from -50 to $-20 \mathrm{mV}$ for $5-50 \mathrm{~ms}$, the presynaptic $I_{\mathrm{Ca}}$ was activated in the cone. In response to the depolarization, the evoked EPSC was recorded from the horizontal cell (voltage clamped at -60 to $-85 \mathrm{mV}$ ) (Fig. $3 A$, left, thin trace). Application of L-AP-4 $(50-200 \mu \mathrm{M})$ inhibited the cone $I_{\mathrm{Ca}}$ and reduced the evoked EPSCs (peak amplitude, $0.50 \pm 0.08$ of control, $p<0.01$; total charge, $0.48 \pm 0.11$ of control, $p<0.05$; $n=8$ ) (Fig. $3 A$, right, filled bars). The inhibitory effects of L-AP-4 were recovered after washout (peak amplitude, $0.94 \pm 0.06$ of control; total charge, $0.86 \pm 0.09$ of control; $n=5$ ) (Fig. $3 A$, right, open bars).

We also examined the effects of L-AP-4 on synaptic transmission from a cone to an OFF bipolar cell (Fig. 3B, left). Similarly, L-AP-4 (100-200 $\mu \mathrm{M})$ suppressed the peak amplitude and total charge of the cone-evoked EPSCs significantly (peak amplitude, $0.68 \pm 0.03$ of control, $p<0.01$; total charge, $0.56 \pm 0.04$ of control, $p<0.01 ; n=8$ ) (Fig. $3 B$, right, filled bars). This effect was reversible (peak amplitude, $0.96 \pm 0.01$ of control; total charge, $0.79 \pm 0.03$ of control; $n=3$ ) (Fig. $3 B$, right, open bars).

L-AP-4 did not affect the glutamate-induced currents in the postsynaptic neurons (Fig. $1 D, E$ ), and thus, L-AP-4 suppressed synaptic transmission from cones to the second-order neurons through reduction of the cone $I_{\mathrm{Ca}}$ and glutamate release.

Inhibition of the cone $I_{\mathrm{Ca}}$ was mediated not by horizontal cell activity but by activation of G-proteins in cones

It has been reported previously (Verweij et al., 1996; Hirasawa and Kaneko, 2003) that changes in the membrane potential of neighboring horizontal cells by surround illumination or by
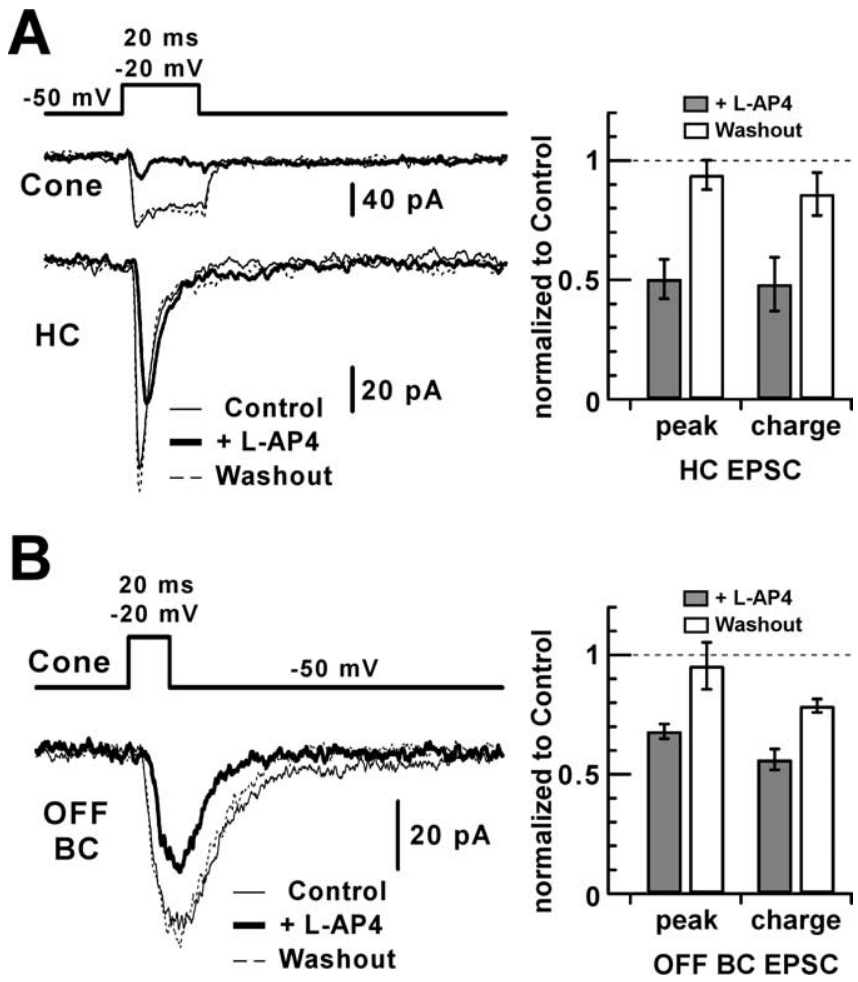

Figure 3. Effects of L-AP-4 on synaptic transmission from cones to the synaptically connected second-order neurons. $\boldsymbol{A}$, Left, A $20 \mathrm{~ms}$ depolarizing pulse to $-20 \mathrm{mV}$ (top) elicited a sustained inward $I_{\mathrm{Ca}}$ in a cone (middle) and evoked an EPSC in a horizontal cell maintained at $-60 \mathrm{mV}$ (bottom). The currents before (Control, thin traces), during (+ L-AP-4, thick traces), and after application of L-AP-4 (200 $\mu \mathrm{m}$ ) (Washout, dotted traces) are superimposed. Baselines of the evoked EPSCS were shifted arbitrarily for a better view. Right, Pooled data of the peak amplitude and total charge of the cone-evoked EPSCs normalized to the values in Control (filled bars, $+\mathrm{L}-\mathrm{AP}-4, n=8$; open bars, Washout, $n=5$ ). L-AP-4 ranged between 50 and $200 \mu \mathrm{m} . \boldsymbol{B}$, Left, Effects of L-AP-4 (100-200 $\mu \mathrm{m})$ on the cone-evoked EPSCs in OFF bipolar cells. Right, Pooled data (filled bars, $+\mathrm{L}-\mathrm{AP}-4, n=8$; open bars, Washout, $n=3$ ). Error bars represent SEM.

bath-applied kainate lead to the modulation of the cone $I_{\mathrm{Ca}}$ and that this feedback modulation (cone $\rightarrow$ horizontal cell $\rightarrow$ cone) disappears by blocking synaptic transmission from cones to horizontal cells with non-NMDA receptor antagonists. It is possible that the cone $I_{\mathrm{Ca}}$ may be modulated indirectly by L-AP-4 through the horizontal cell-mediated feedback. However, this was unlikely because application of L-AP-4 $(200 \mu \mathrm{M})$ still inhibited the cone $I_{\mathrm{Ca}}$ in the presence of NBQX $(10 \mu \mathrm{M})$ (Fig. $4 A$, thick trace).

It is generally accepted that mGluRs are G-protein-coupled receptors (Nakanishi, 1994; Conn and Pin, 1997). To examine a possible involvement of G-proteins in the $I_{\mathrm{Ca}}$ modulation, the G-protein inhibitor GDP $\beta S(0.5-3 \mathrm{~mm})$ was introduced into a cone via a recording pipette. More than 3 min after establishment of the whole-cell configuration, which should allow for adequate diffusion of GDP $\beta$ S into the cell, L-AP-4 (200 $\mu \mathrm{M})$ no longer suppressed the cone $I_{\mathrm{Ca}}$ (Fig. $4 B$ ). L-AP-4 affected neither the peak amplitude nor total charge of the cone $I_{\mathrm{Ca}}$ (Fig. 4C) (peak amplitude, $0.98 \pm 0.03$ of control, $p=0.68$; total charge, $0.97 \pm$ 0.06 of control, $p=0.90 ; n=6)$. Therefore, $\mathrm{L}-\mathrm{AP}-4$ inhibited the cone $I_{\mathrm{Ca}}$ through activation of G-proteins in cones. This result supports our hypothesis that newt cones have G-protein-coupled group III mGluRs, although the presence of mGluR molecules has not yet been demonstrated in the newt retina. 

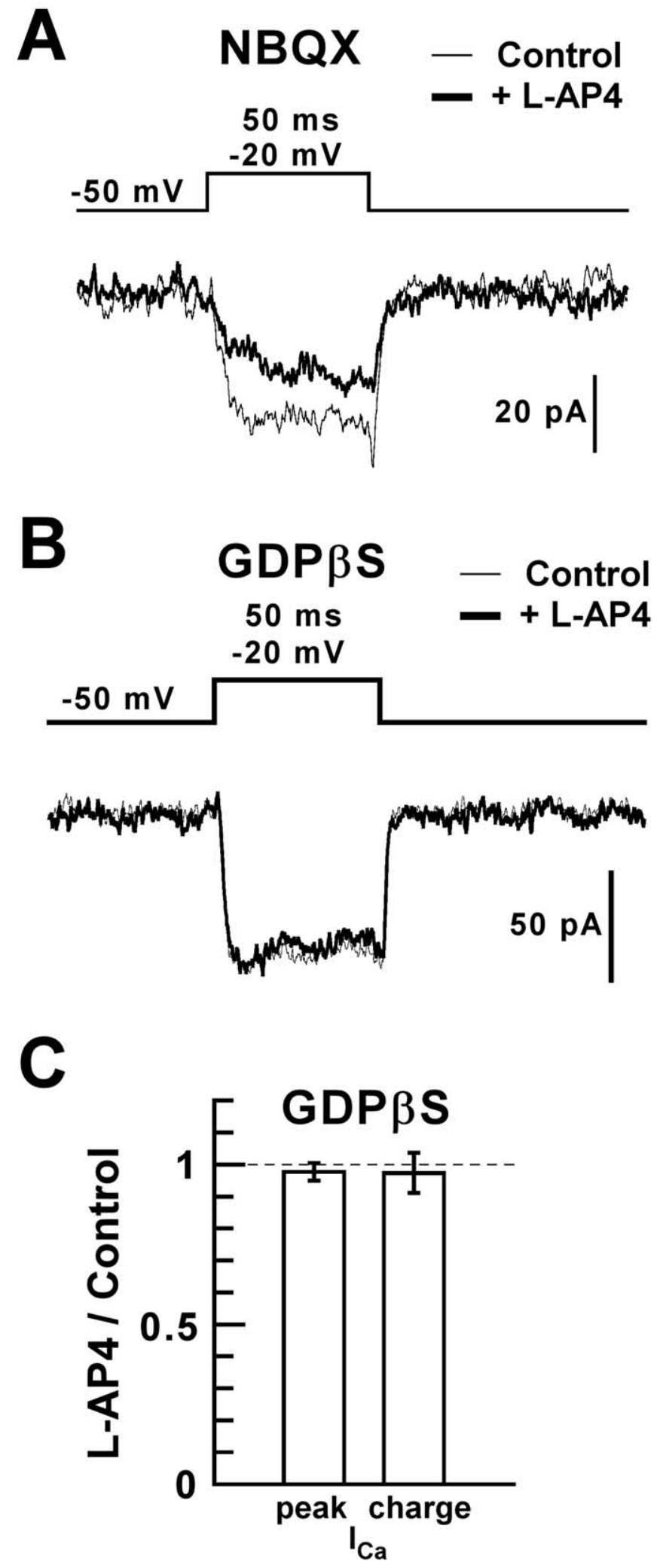

Figure 4. Inhibition of the cone $I_{\mathrm{Ca}}$ by L-AP-4 involves activation of G-proteins in cones but not horizontal cell-mediated feedback. $A$, Effects of $\mathrm{L}-\mathrm{AP}-4$ on the cone $I_{\mathrm{Ca}}$ in the presence of NBQX $(10 \mu \mathrm{M})$, which blocked non-NMDA receptors in horizontal cells. The cone was depolarized from -50 to $-20 \mathrm{mV}$ for $50 \mathrm{~ms}$. $\boldsymbol{B}$, Effects of L-AP-4 on $I_{\mathrm{Ca}}$ recorded from a GDP $\beta S(0.5$ $\mathrm{mm})$-filled cone. $C$, Pooled data of the peak amplitude and total charge of the cone $I_{\mathrm{Ca}}(n=6)$. The concentration of GDP $\beta$ S ranged between 0.5 and $3 \mathrm{~mm}$. Error bars represent SEM.
Exocytosed protons and group III mGluRs modulated the cone $I_{\mathrm{Ca}}$ independently

Synaptic vesicles are acidified by an ATP-dependent proton pump that provides the driving force for loading neurotransmitters (Liu and Edwards, 1997). Recently, it has been demonstrated that exocytosed protons feedback to suppress $I_{\mathrm{Ca}}$ in mammalian cones (DeVries, 2001). If $I_{\mathrm{Ca}}$ induced by a prepulse triggers a burst of exocytosis, a subsequent test pulse will reduce the amount of exocytosis resulting from depletion of releasable synaptic vesicles. This leads to disinhibition (that is, apparent facilitation) of $I_{\mathrm{Ca}}$ during the test pulse, because the test pulse does not induce copious release of transmitters and protons. Thus, using the prepulse protocol, we examined whether exocytosed protons also affected the cone $I_{\mathrm{Ca}}$ in the newt retina.

To identify inhibition of $I_{\mathrm{Ca}}$ associated with exocytosis, we performed simultaneous recordings from pairs of a cone and an OFF bipolar cell and monitored both the cone $I_{\mathrm{Ca}}$ and the evoked EPSC. A $50 \mathrm{~ms}$ prepulse to $+60 \mathrm{mV}$ elicited a tail $I_{\mathrm{Ca}}$ at the prepulse offset (Fig. $5 A$, middle, thick trace marked by arrow) and evoked EPSC in the OFF bipolar cell (Fig. 5A, bottom, thick trace). The tail $I_{\mathrm{Ca}}$ was abolished by nifedipine (data not shown). However, a subsequent test pulse to $-20 \mathrm{mV}$ failed to evoke EPSCs in the OFF bipolar cell (Fig. $5 A$, bottom, thick trace), although the test pulse still elicited $I_{\mathrm{Ca}}$ (Fig. $5 \mathrm{~A}$, middle, thick trace). In contrast, when the prepulse did not precede, the test pulse elicited both the cone $I_{\mathrm{Ca}}$ (Fig. $5 A$, middle, thin trace) and the evoked EPSC (Fig. $5 A$, bottom, thin trace). It should be noted that the amplitude of the cone $I_{\mathrm{Ca}}$ was smaller during the test pulse when the prepulse did not precede (Fig. $5 A$, middle, thin trace). These results may indicate that inhibition of the cone $I_{\mathrm{Ca}}$ is associated with the amount of exocytosis (DeVries, 2001). Prepulse disinhibition of $I_{\mathrm{Ca}}$ could be more clearly seen when the test pulse duration was prolonged to $50 \mathrm{~ms}$, and the prepulse accelerated the activation kinetics of the cone $I_{\mathrm{Ca}}$ (Fig. $5 \mathrm{~B}$, left, thick trace). The total charge of $I_{\mathrm{Ca}}$ evoked by the test pulse was significantly increased by the prepulse (Fig. $5 B$, right) (charge ratio, $1.50 \pm 0.19 ; n=19 ; p<0.01$ ). The prepulse disinhibition remained even in the presence of NBQX $(10 \mu \mathrm{M})$, excluding horizontal cell-mediated feedback as a mechanism $(n=2)$ (data not shown).

If the prepulse disinhibition was related to the exocytosed protons, this phenomenon would disappear when the extracellular $\mathrm{pH}$ buffering capacity was raised (DeVries, 2001; Palmer et al., 2003). Indeed, the prepulse disinhibition disappeared in a highHEPES (40 mM)-buffered extracellular solution (Fig. 5C) (charge ratio, $0.99 \pm 0.03 ; n=5 ; p=0.82$ ). These results are consistent with the data of the mammalian cone $I_{\mathrm{Ca}}$ reported by DeVries (2001) and suggest that the newt cone $I_{\mathrm{Ca}}$ is inhibited not only by the activation of group III mGluRs but also by the exocytosed protons. Prepulse disinhibition of the cone $I_{\mathrm{Ca}}$ is caused mainly by relief from $I_{\mathrm{Ca}}$ inhibition by exocytosed protons under this condition (application of the test pulse to $-20 \mathrm{mV}$ in the control solution).

The prepulse protocol was usually used for testing the involvement of membrane-delimited pathways of G-proteins (direct action of G-proteins) in $I_{\mathrm{Ca}}$ inhibition (Boland and Bean, 1993; Campbell et al., 1995; Zamponi and Snutch, 1998; Dolphin, 2003). The key features of the membrane-delimited G-proteindependent $I_{\mathrm{Ca}}$ inhibition are slowing of the $I_{\mathrm{Ca}}$ activation kinetics and removal of $I_{\mathrm{Ca}}$ inhibition by a depolarizing prepulse (that is, prepulse facilitation). To test whether membrane-delimited pathway of G-proteins were involved in mGluR-mediated inhibition of the cone $I_{\mathrm{Ca}}$, we applied the prepulse protocol (prepulse 

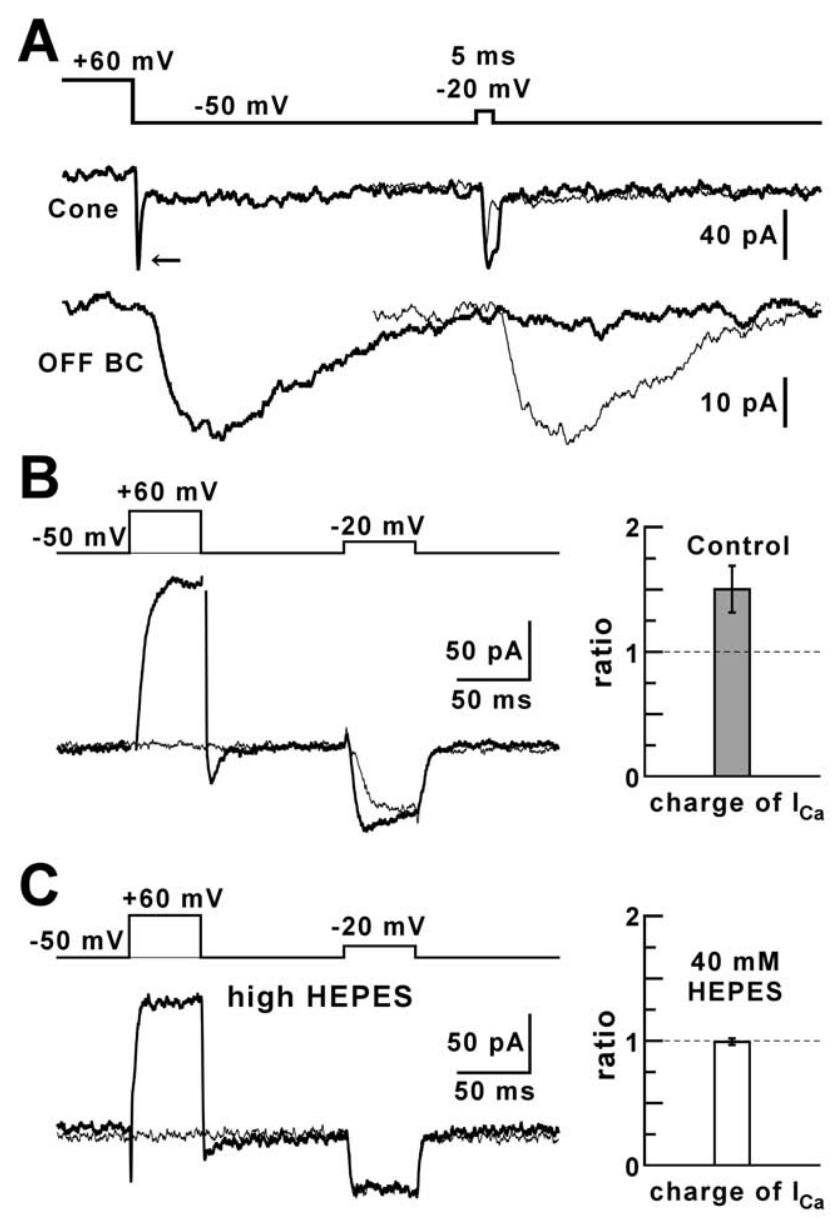

D

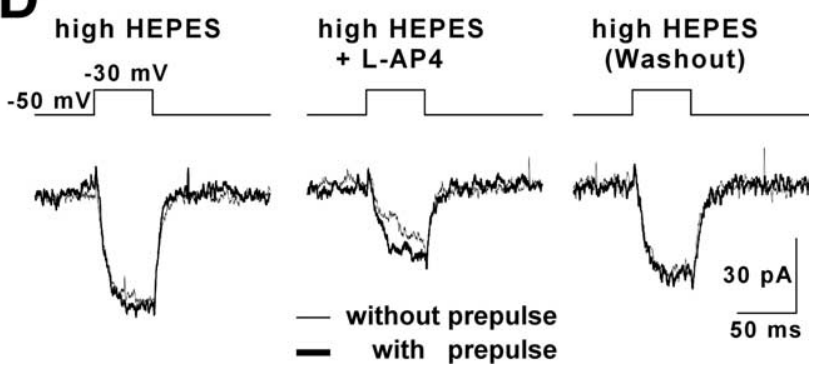

Figure 5. Inhibition of the cone $I_{\mathrm{Ca}}$ by group III mGluRs and by exocytosed protons. $\boldsymbol{A}$, Prepulse disinhibition observed in the control solution ( $5 \mathrm{~mm}$ HEPES). Paired recordings were performed from a cone (voltage clamped at $-50 \mathrm{mV}$ ) and a synaptically connected OFF bipolar cell (voltage clamped at $-80 \mathrm{mV}$ ). A $50 \mathrm{~ms}$ prepulse from -50 to $+60 \mathrm{mV}$ preceded a 5 ms test pulse to $-20 \mathrm{mV}$ (thick traces). The interval between the two pulses was $100 \mathrm{~ms}$. Thin traces were obtained without prepulse. The arrow indicates a tail $I_{\mathrm{Ca}}$ elicited at the prepulse offset. $\boldsymbol{B}$, Left, Current traces recorded from the cone with (thick trace) and without (thin trace) prepulse. Test pulse duration was prolonged to $50 \mathrm{~ms}$. Right, Charge ratio was calculated as the ratio of the total charge of the cone $I_{\mathrm{Ca}}$ during the test pulse with prepulse to that without prepulse ( $n=$ 19). C, No prepulse disinhibition in the high ( $40 \mathrm{~mm}$ )-HEPES-buffered extracellular saline, $\mathrm{pH} 7.8$ (similar to the control saline). The same prepulse protocol is used as in $\boldsymbol{B}$. Left, Current traces from the cone. Right, Charge ratio $(n=5)$. $\boldsymbol{D}$, Effects of the prepulse on the cone $I_{\mathrm{Ca}}$ in the high-HEPES-buffered extracellular saline before (left), during (middle), and after application of L-AP-4 (200 $\mu \mathrm{m})$ (right). The same prepulse protocol as $\boldsymbol{B}$ except that test pulses to $-30 \mathrm{mV}$, instead of $-20 \mathrm{mV}$, were applied. Current traces recorded from the cone with (thick trace) and without (thin trace) prepulse are superimposed.

to $+60 \mathrm{mV}$; test pulse to $-30 \mathrm{mV}$ instead of $-20 \mathrm{mV}$ ) to cones in the high-HEPES-buffered extracellular solution, in which $I_{\mathrm{Ca}}$ inhibition by exocytosed protons was excluded, and examined the effect of L-AP-4. Before application of L-AP-4 (200 $\mu \mathrm{M})$, the pre- pulse did not affect the cone $I_{\mathrm{Ca}}$ elicited by the test pulse (Fig. $5 D$, left). Application of L-AP-4 slowed down the activation kinetics and reduced the peak amplitude of the $I_{\mathrm{Ca}}$ (Fig. $5 D$, compare middle, thin trace with left, thin trace), and inhibition of $I_{\mathrm{Ca}}$ by L-AP-4 was partially relieved by the prepulse (Fig. 5D, middle, thick trace), consistent with direct action of G-proteins. The effect of L-AP-4 was reversible (Fig. 5D, right). It should also be noted that prepulse in the presence of L-AP-4 did not completely restore the cone $I_{\mathrm{Ca}}$ to the similar amplitude in the absence of L-AP-4 (Fig. 5D, compare middle, thick trace with left, thick trace). Another voltage-independent inhibitory pathway might be involved in the effect of L-AP-4, and direct action of G-proteins would not be predominant. We cannot deny the possibility that the prepulse used in the present experiment was not strong enough to relieve membrane-delimited G-protein inhibition, but strong prepulses often deteriorated the cells. Here, we point out that group III mGluRs and exocytosed protons modulate the cone $I_{\mathrm{Ca}}$ independently.

Neither L-AP-4 nor prepulse affected the L-type $I_{\mathrm{Ca}}$ in rods and synaptic transmission from rods to the second-order neurons

We examined whether L-AP-4 and prepulses also affected $I_{\mathrm{Ca}}$ in rods (Fig. 6 A). A $50 \mathrm{~ms}$ depolarizing pulse from -50 to $-20 \mathrm{mV}$ elicited a sustained inward current (Fig. $6 B$, left, Control). The current was identified as the L-type $I_{\mathrm{Ca}}$, because it was completely blocked by nifedipine $(10 \mu \mathrm{M})$ (Fig. $6 \mathrm{~B}$, right, +Nifedipine). L-AP-4 did not affect the rod $I_{\mathrm{Ca}}$ (Fig. $6 \mathrm{~B}$, left, + L-AP-4). Specifically, L-AP-4 (100-200 $\mu \mathrm{M})$ did not change the peak amplitude (Control, $71.64 \pm 7.63 \mathrm{pA}$; $+\mathrm{L}-\mathrm{AP}-4,70.05 \pm 7.52 \mathrm{pA} ; n=7 ; p=$

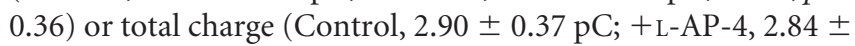
0.35 pC; $n=7 ; p=0.53$ ) of the L-type $I_{\mathrm{Ca}}$ (Fig. $6 C$ ).

It should be noted that activation kinetics of the $\operatorname{rod} I_{\mathrm{Ca}}$ (time constant, $1.01 \pm 0.15 \mathrm{~ms} ; n=9$ ) was faster than that of the cone $I_{\mathrm{Ca}}(4.52 \pm 0.55 \mathrm{~ms} ; n=26)$. Because the $\operatorname{rod} I_{\mathrm{Ca}}$ was activated more rapidly and did not inactivate (Fig. $6 B$ ), the $I-V$ relationship could reliably be obtained from voltage ramps (Fig. $6 D$, Control). $V_{\text {half }}$ of the $\operatorname{rod} I_{\mathrm{Ca}}$ was $-32.46 \pm 1.07 \mathrm{mV}(n=8)$, similar to the one in cones $(-34.23 \pm 0.44 \mathrm{mV} ; n=18)$. L-AP-4 had little effect on the $I-V$ relationship of the $\operatorname{rod} I_{\mathrm{Ca}}$ (Fig. $6 D$, $+\mathrm{L}-\mathrm{AP}-4)\left(V_{\text {half }}\right.$ shift, $\left.+0.76 \pm 0.27 \mathrm{mV} ; n=6\right)$. A prepulse to $+60 \mathrm{mV}$ did not affect the amplitude of the $\operatorname{rod} I_{\mathrm{Ca}}$ during a test pulse even within a few minutes after whole-cell break-in (Fig. $6 E$ ) (charge ratio, $0.97 \pm 0.02 ; n=4 ; p=0.27$ ), although the tail $I_{\mathrm{Ca}}$ was effectively triggered at the cessation of the prepulse (Fig. $6 E$, left, arrow). We also tested the effects of prepulse on the rod $I_{\mathrm{Ca}}$ in a bicarbonate-buffered extracellular saline, but we could not detect any changes $(n=2)$.

We further investigated whether L-AP-4 affected synaptic transmission from rods to the second-order neurons (OFF bipolar cells and horizontal cells) by paired recordings. A depolarizing pulse to $-20 \mathrm{mV}$ elicited the rod $I_{\mathrm{Ca}}$ and evoked an EPSC at a synaptically connected horizontal cell clamped at $-85 \mathrm{mV}$. L-AP-4 $(100 \mu \mathrm{M})$ affected neither the $\operatorname{rod} I_{\mathrm{Ca}}$ nor the evoked EPSC in the horizontal cell (Fig. 7A). There were no significant differences in the peak amplitude or total charge of the rod-evoked EPSCs (two horizontal cells and an OFF bipolar cell as postsynaptic cells). Even when the evoked EPSC amplitude was reduced by changing the pulse amplitude $(-35$ instead of $-20 \mathrm{mV})$, the effects of L-AP-4 were not detected (Fig. $7 B$ ), excluding possible occlusion of the L-AP-4 effect by postsynaptic receptor saturation (Tang et al., 1994; Auger and Marty, 2000). 


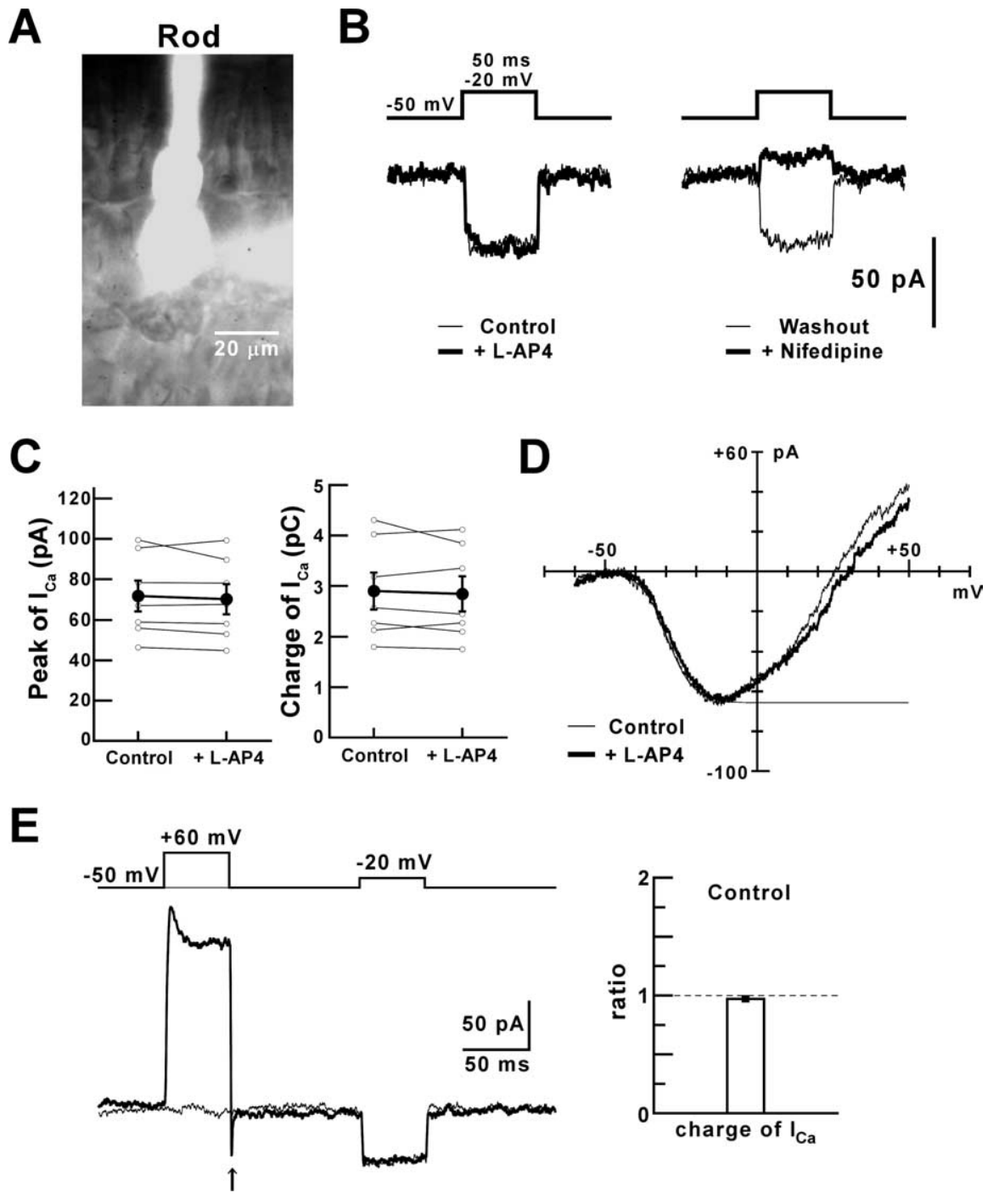

Figure 6. No effect of $\mathrm{L}-\mathrm{AP}-4$ and prepulses on the rod $\mathrm{L}$-type $I_{\mathrm{Ca}} \cdot \boldsymbol{A}$, Fluorescent image of a rod stained with Lucifer yellow. $\boldsymbol{B}$, A $50 \mathrm{~ms}$ depolarizing pulse to $-20 \mathrm{mV}$ was applied to elicit the rod $I_{\mathrm{ca}}$. Left, The current was measured before (thin trace) and during (thick trace) application of L-AP-4 (200 $\mu \mathrm{m})$. Right, After washout of L-AP-4, the current was measured before (thin trace) and during (thick trace) application of nifedipine $(10 \mu \mathrm{M})$. C, Effects of L-AP-4 on the peak amplitude and total charge of the nifedipine-sensitive $I_{\mathrm{Ca}_{\mathrm{a}}}(n=7)$. Filled and open circles represent mean values and individual data points, respectively. $\boldsymbol{D}$, Effect of L-AP-4 on the $I_{\mathrm{Ca}}-V$ relationship. The relationship was obtained by voltage ramps from -60 to $+60 \mathrm{mV}$ at the rate of $120 \mathrm{mV} / 300$ $\mathrm{ms}$. A sigmoid curve was fitted to the increasing portion of the $I_{\mathrm{Ca}}-V$ relationship. Fitted parameters to the control were $-68.1 \mathrm{pA}$ $\left(I_{\max }\right),-30.4 \mathrm{mV}\left(V_{\text {haff }}\right)$, and $-4.7 \mathrm{mV}\left(V_{\text {slope }}\right) . \boldsymbol{E}$, The prepulse protocol is the same as in Figure $5 B$. Left, Current traces with (thick trace) and without (thin trace) prepulse. An arrow indicates the tail $I_{\text {Ca. }}$ Right, Charge ratio of the rod $I_{\text {Ca }}(n=4)$.

lease from a cone but not from a rod. This is compatible with the observation that L-AP-4 reduced cone-dominated light responses of the second-order neurons in carp and tiger salamander retinas (Nawy et al., 1989; Hare and Owen, 1992; Hirasawa et al., 2002). Furthermore, we identified the cone L-type $I_{\mathrm{Ca}}$ as the target of presynaptic group III mGluR action. We could not exclude the possibility that modulation of other ion channels (Cochilla and Alford, 1998) and release machinery (Scanziani et al., 1995; Wu and Saggau, 1997) might also contribute to the inhibition of glutamate release. The $\mathrm{Ca}^{2+}$ influx through cGMP-gated channels can also initiate exocytosis in cones (Rieke and Schwartz, 1994). Because L-AP-4 had no detectable effect on the light-induced cGMP-gated currents in newt cones (data not shown), presynaptic inhibition observed here does not involve cGMP-gated channels in newt cones. cGMP-gated channels might play a different role in controlling glutamate release, such as modulation by NO (Savchenko et al., 1997).

Because cones make the first synapses in the retina, endogenous activation of presynaptic group III mGluRs may influence not only the OFF pathway but also the ON pathway, which could not be investigated by the pharmacological approach used here. LY341495, an antagonist of group II/III mGluRs, could increase light responses of OFF bipolar cells, suggesting possible endogenous activation of cone presynaptic mGluRs. However, we could not estimate the extent of their endogenous activation because of the lack of group III mGluR-specific antagonists. Cones can function over a wider range of light intensities than rods (Miller et al., 1994; Ebrey and Koutalos, 2001). Thus, we suppose that group III mGluRs of cones may serve as negative-feedback autoreceptors to avoid depletion of releasable vesicles and may broaden the dynamic range of their synaptic outputs in a light-adapted

\section{Discussion}

The present study demonstrated that activation of group III mGluRs by L-AP-4 reduced glutamate release from cones but not from rods (Figs. 1, 3, 7). Group III mGluRs inhibited the cone L-type $I_{\mathrm{Ca}}$ by shifting the voltage dependence of activation to more positive potentials (Fig. 2). L-AP-4 most effectively reduced the cone $I_{\mathrm{Ca}}$ from -50 to $-20 \mathrm{mV}$, the physiological range of membrane potential of newt cones (Fig. 2). The inhibition involved activation of G-proteins in cones (Fig. 4). In addition to group III mGluRs, exocytosed protons also inhibited the cone $I_{\mathrm{Ca}}$ (Fig. 5), which confirms the results of DeVries (2001). In contrast, neither L-AP-4 nor exocytosed protons affected the rod L-type $I_{\mathrm{Ca}}$ (Fig. 6).

Using simultaneous paired recordings from synaptically connected neurons, we showed that L-AP-4 inhibited glutamate re- condition. Kinetics of synaptic transmission is faster in cone synapses than rod synapses (Schnapf and Copenhagen, 1982), and negative feedback by cone mGluRs may help this phenomenon. Additionally, if cone mGluRs are activated by glutamate spilt over from adjacent photoreceptors, the mGluRs might affect the formation of concentric receptive field of second-order neurons and might improve spatial resolution. This is likely to happen in the ribbon synapses where glutamate release is more tonic, compared with conventional synapses between fast-spiking neurons (Rieke and Schwartz, 1996; Matsui et al., 1998; von Gersdorff, 2001; Parsons and Sterling, 2003). In contrast to mammals, cone and rod pathways are not well segregated in lower vertebrates, and synaptic inputs from cones and rods converge on most secondorder neurons (Lasansky, 1973, 1978; Yang and Wu, 1996, 1997; Brandstätter and Hack, 2001). Thus, the role of cone mGluRs on 


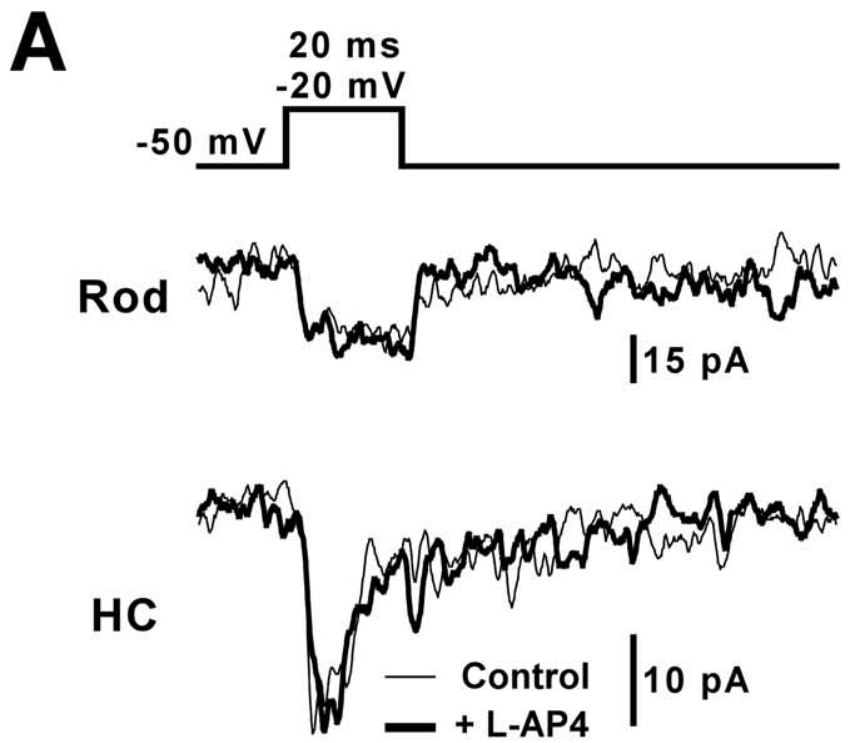

B
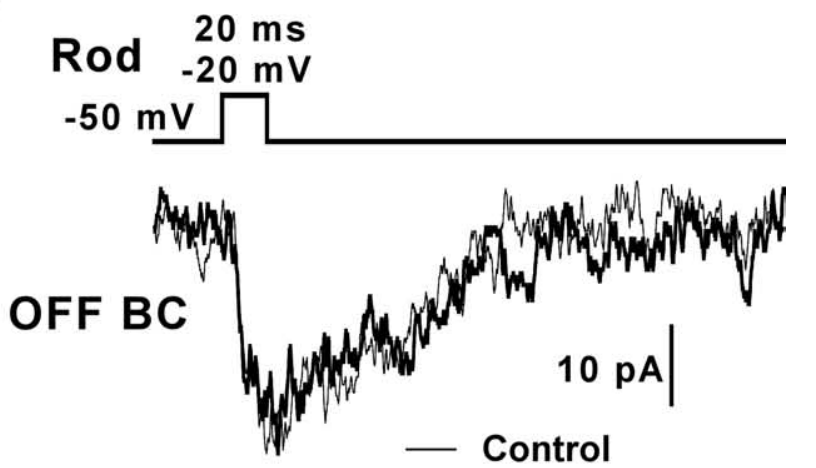

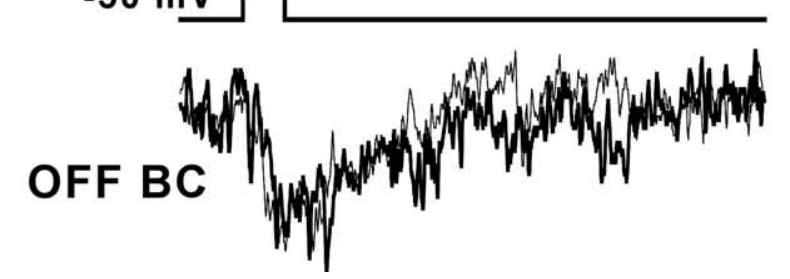

Figure 7. No effect of L-AP-4 on synaptic transmission from rods to the synaptically connected second-order neurons. $A, A 20$ ms depolarizing pulse from -50 to $-20 \mathrm{mV}$ elicited the $\mathrm{rod} I_{\mathrm{Ca}}($ Rod; middle) and the evoked EPSC in a horizontal cell (HC) held at $-85 \mathrm{mV}$ (bottom). The currents were obtained before (thin traces) and during (thick traces) application of L-AP-4 $(100 \mu \mathrm{m}) . \boldsymbol{B}$, Effects of L-AP-4 on the rod-evoked (Rod) EPSCs in an OFF bipolar cell (OFF BC) held at $-80 \mathrm{mV}$. The rod was depolarized to $-20 \mathrm{mV}$ (top traces) or $-35 \mathrm{mV}$ (bottom traces).

visual information processing might be complicated when both cones and rods are functional in the mesopic state. Furthermore, Koulen and Brandstätter (2002) have shown in the rat retina that immunoreactivity of mGluR8, one of the group III mGluRs, is present at approximately all rod terminals and $25 \%$ of cone terminals. Their immunocytochemical findings in the rat retina are not consistent with our physiological results in the newt retina. The group III mGluRs in mammalian cones may play less significant roles than those in amphibian cones.

It has been reported that L-AP-4 inhibited glutamatergic synaptic transmission from bipolar cells to ganglion cells in the inner retina (Awatramani and Slaughter, 2001; Higgs et al., 2002). We confirmed in the newt retina that L-AP-4 reduced OFF responses of the light-evoked EPSCs in putative ganglion cells and that L-AP-4 did not affect the postsynaptic glutamate conductance of these cells (data not shown). However, $\mathrm{L}-\mathrm{AP}-4$ did not affect $I_{\mathrm{Ca}}$ in bipolar cells (OFF bipolar cells, $n=6$; ON bipolar cells, $n=7$ ). L-AP-4 may have no direct effect on synaptic transmission in the inner retina and reduction of the OFF responses in putative ganglion cells may rather reflect reduction of synaptic inputs to OFF bipolar cells. Alternatively, L-AP-4 may inhibit transmitter release by modulation of other ion channels or release machinery in bipolar cells (Scanziani et al., 1995; Wu and Saggau, 1997; Cochilla and Alford, 1998). It is interesting to note that one of the group III mGluRs, mGluR7, has been found on bipolar cell terminals in the mammalian retina in addition to group I mGluRs on their dendritic tips (Brandstätter et al., 1998). Functional roles of these mGluRs should be investigated by simultaneous presynaptic and postsynaptic recordings in the future.

Besides group III mGluRs, exocytosed protons inhibited the cone $I_{\mathrm{Ca}}$ (DeVries, 2001) in the newt retina independently. $I_{\mathrm{Ca}}$ of ON bipolar cells is also sensitive to exocytosed protons (Palmer et al., 2003). Inhibition of the cone $I_{\mathrm{Ca}}$ by exocytosed protons occurred within a few milliseconds after activation of $I_{\mathrm{Ca}}$ (Fig. 5). Such a fast negative-feedback mechanism would reduce depletion of the releasable synaptic vesicles effectively and enable cones to follow high-frequency light stimuli, improving time resolution of visual perception and contributing to detecting moving stimuli. The effect of exocytosed protons may be more prominent at more depolarized potentials where the amount of exocytosis is high. In contrast, the mGluR effect is more effective at more negative potentials (Fig. $2 \mathrm{~F}$ ). The two modulatory pathways might cover different ranges of the cone membrane potential.

Although the cone $I_{\mathrm{Ca}}$ and the $\operatorname{rod} I_{\mathrm{Ca}}$ were both identified as L-type (Figs. 2, 6), only the cone $I_{\mathrm{Ca}}$ was inhibited by group III mGluRs and exocytosed protons. L-type calcium channels are heteromeric protein complexes containing a principal poreforming $\alpha_{1}$ subunit and auxiliary $\beta$ and $\alpha_{2} \delta$ subunits (Dolphin, 1999; Catterall, 2000). Whereas $\alpha_{1}$ subunits determine the principal biophysical and pharmacological properties of the channel, $\beta$ subunits modulate cell surface expression, voltage dependence, and opening kinetics. The other subunits have been less investigated thus far. It has been shown that three different $\alpha_{1}$ subunits of L-type channels, $\alpha_{1 \mathrm{C}}, \alpha_{1 \mathrm{D}}$, and $\alpha_{1 \mathrm{~F}}$, are expressed in the OPL of the retina (Nachman-Clewner et al., 1999; Firth et al., 2001; Morgans, 2001; Xu et al., 2002). Heterogeneity of calcium channel subtypes among cones has been suggested in the cone-dominated retina of the tree shrew (Morgans, 1999). The different properties between the cone $I_{\mathrm{Ca}}$ and the $\operatorname{rod} I_{\mathrm{Ca}}$ in the newt retina might be derived from different subunit compositions. In the present study, $\mathrm{pH}$ sensitivity of the L-type $I_{\mathrm{Ca}}$ was not examined. Ineffectiveness of the prepulse on the $\operatorname{rod} I_{\mathrm{Ca}}$ might result from different $\mathrm{pH}$ sensitivity of the rod $I_{\mathrm{Ca}}$ or the different architecture of rod output synapses.

It is well established that $\mathrm{N}$ - and P/Q-type calcium channels are inhibited by G-protein-coupled receptors via a membranedelimited pathway where $\beta \gamma$ subunits of G-proteins directly interact with calcium channels (direct effect of G-proteins) (Hille, 1994; Zamponi and Snutch, 1998; Dolphin, 2003). In N- and $\mathrm{P} / \mathrm{Q}$-type calcium channels, the inhibition can be relieved by large depolarizations, resulting in prepulse facilitation. Because of slowing of the activation kinetics by L-AP-4 (Figs. 2, 5D) and prepulse facilitation in the presence of $40 \mathrm{mM}$ HEPES and L-AP-4, direct modulation by G-proteins is a likely mechanism at cones. 
Similar results have been reported for L-type $I_{\mathrm{Ca}}$ in neurosecretory cells (Ammälä et al., 1992; Degtiar et al., 1997). However, mechanisms of L-type $I_{\mathrm{Ca}}$ modulation are heterogeneous (Dolphin, 1999). Direct G-protein inhibition does not always accompany prepulse facilitation (Dolphin, 1999; Carbone et al., 2001). Molecular mechanisms that are involved in direct G-protein modulation of L-type $I_{\mathrm{Ca}}$ have yet to be elucidated. In the expression system of $\alpha_{1}$ subunits of L-type channels, voltage-dependent G-protein modulation was not found in the currents through channels constituted of the $\alpha_{1 \mathrm{C}}, \alpha_{1 \mathrm{D}}$, or $\alpha_{1 \mathrm{~F}}$ subunit (Zhang et al., 1996; Bell et al., 2001; Koschak et al., 2003). Other isoforms or undiscovered accessory proteins may be required for G-protein modulation. It has been reported previously (Stella and Thoreson, 2000; Straiker and Sullivan, 2003) in large single cones of the tiger salamander retina that dopamine $\mathrm{D}_{2}$ receptors and cannabinoid $\mathrm{CB}_{1}$ receptors, which activate $\mathrm{G}_{\mathrm{i} / \mathrm{o}}$-type $\mathrm{G}$-proteins, suppress $I_{\mathrm{Ca}}$ by reducing cAMP levels and protein kinase A activity. It is also proposed in retinal ganglion cells that group III mGluRs activate phospholipase $C$ via $G$-proteins and induce production of $\mathrm{IP}_{3}$ and calcium release from internal stores, leading to suppression of L-type calcium channels (Shen and Slaughter, 1998). Precise identification of the signaling pathways of the mGluR modulation in cones remains to be elucidated.

\section{References}

Alapakkam P, Sampath AP, Rieke F (2004) Selective transmission of single photon responses by saturation at the rod-to-rod bipolar synapse. Neuron 41:431-443.

Ammälä C, Berggren PO, Bokvist K, Rorsman P (1992) Inhibition of L-type calcium channels by internal GTP $\gamma S$ in mouse pancreatic beta cells. Pflügers Arch 420:72-77.

Auger C, Marty A (2000) Quantal currents at single-site central synapses. J Physiol (Lond) 526:3-11.

Awatramani GB, Slaughter MM (2001) Intensity-dependent, rapid activation of presynaptic metabotropic glutamate receptors at a central synapse. J Neurosci 21:741-749.

Barnes S, Hille B (1989) Ionic channels of the inner segment of tiger salamander cone photoreceptors. J Gen Physiol 94:719-743.

Bell DC, Butcher AJ, Berrow NS, Page KM, Brust PF, Nesterova A, Stauderman KA, Seabrook GR, Nürnberg B, Dolphin AC (2001) Biophysical properties, pharmacology, and modulation of human, neuronal L-type $\left(\alpha_{1 \mathrm{D}}, \mathrm{Ca}_{\mathrm{V}} 1.3\right)$ voltage-dependent calcium currents. J Neurophysiol 85:816-827.

Boland LM, Bean BP (1993) Modulation of N-type calcium channels in bullfrog sympathetic neurons by luteinizing hormone-releasing hormone: kinetics and voltage dependence. J Neurosci 13:516-533.

Brandstätter JH, Hack I (2001) Localization of glutamate receptors at a complex synapse. The mammalian photoreceptor synapse. Cell Tissue Res 303:1-14.

Brandstätter JH, Koulen P, Wässle H (1998) Diversity of glutamate receptors in the mammalian retina. Vision Res 38:1385-1397.

Campbell V, Berrow NS, Fitzgerald EM, Brickley K, Dolphin AC (1995) Inhibition of the interaction of $G$ protein $G_{o}$ with calcium channels by the calcium channel beta-subunit in rat neurones. J Physiol (Lond) 485:365-372.

Carbone E, Carabelli V, Cesetti T, Baldelli P, Hernández-Guijo JM, Giusta L (2001) G-protein- and cAMP-dependent L-channel gating modulation: a manyfold system to control calcium entry in neurosecretory cells. Pflügers Arch 442:801-813.

Catterall WA (2000) Structure and regulation of voltage-gated $\mathrm{Ca}^{2+}$ channels. Annu Rev Cell Dev Biol 16:521-555.

Cochilla AJ, Alford S (1998) Metabotropic glutamate receptor-mediated control of neurotransmitter release. Neuron 20:1007-1016.

Conn PJ, Pin JP (1997) Pharmacology and functions of metabotropic glutamate receptors. Annu Rev Pharmacol Toxicol 37:205-237.

Contractor A, Gereau IV RW, Green T, Heinemann SF (1998) Direct effects of metabotropic glutamate receptor compounds on native and recombinant $N$-methyl-D-aspartate receptors. Proc Natl Acad Sci USA 95:8969-8974.
Copenhagen DR, Jahr CE (1989) Release of endogenous excitatory amino acids from turtle photoreceptors. Nature 341:536-539.

Corey DP, Dubinsky JM, Schwartz EA (1984) The calcium current in inner segments of rods from the salamander (Ambystoma tigrinum) retina. J Physiol (Lond) 354:557-575.

Degtiar VE, Harhammer R, Nürnberg B (1997) Receptors couple to L-type calcium channels via distinct $G_{o}$ proteins in rat neuroendocrine cell lines. J Physiol (Lond) 502:321-333.

DeVries SH (2001) Exocytosed protons feedback to suppress the $\mathrm{Ca}^{2+}$ current in mammalian cone photoreceptors. Neuron 32:1107-1117.

DeVries SH, Schwartz EA (1999) Kainate receptors mediate synaptic transmission between cones and "Off" bipolar cells in a mammalian retina. Nature 397:157-160.

Dhingra A, Lyubarsky A, Jiang M, Pugh EN, Birnbaumer L, Sterling P, Vardi $\mathrm{N}$ (2000) The light response of ON bipolar neurons requires $\mathrm{G} \alpha$. J Neurosci 20:9053-9058.

Dolphin AC (1999) L-type calcium channel modulation. Adv Second Messenger Phosphoprotein Res 33:153-177.

Dolphin AC (2003) G protein modulation of voltage-gated calcium channels. Pharmacol Rev 55:607-627.

Dowling JE, Ripps H (1973) Effect of magnesium on horizontal cell activity in the skate retina. Nature 242:101-103.

Ebrey T, Koutalos Y (2001) Vertebrate photoreceptors. Prog Retin Eye Res 20:49-94

Firth SI, Morgan IG, Boelen MK, Morgans CW (2001) Localization of voltage-sensitive L-type calcium channels in the chicken retina. Clin Exp Ophthalmol 29:183-187.

Gilbertson TA, Scobey R, Wilson M (1991) Permeation of calcium ions through non-NMDA glutamate channels in retinal bipolar cells. Science 251:1613-1615.

Hare WA, Owen WG (1992) Effects of 2-amino-4-phosphonobutyric acid on cells in the distal layers of the tiger salamander's retina. J Physiol (Lond) 445:741-757.

Higgs MH, Lukasiewicz PD (2002) Activation of group II metabotropic glutamate receptors inhibits glutamate release from salamander retinal photoreceptors. Vis Neurosci 19:275-281.

Higgs MH, Romano C, Lukasiewicz PD (2002) Presynaptic effects of group III metabotropic glutamate receptors on excitatory synaptic transmission in the retina. Neuroscience 115:163-172.

Hille B (1994) Modulation of ion-channel function by G-protein-coupled receptors. Trends Neurosci 17:531-536.

Hirasawa H, Kaneko A (2003) pH changes in the invaginating synaptic cleft mediate feedback from horizontal cells to cone photoreceptors by modulating $\mathrm{Ca}^{2+}$ channels. J Gen Physiol 122:657-671.

Hirasawa H, Shiells R, Yamada M (2002) A metabotropic glutamate receptor regulates transmitter release from cone presynaptic terminals in carp retinal slices. J Gen Physiol 119:55-68.

Jane DE, Pittaway K, Sunter DC, Thomas NK, Watkins JC (1995) New phenylglycine derivatives with potent and selective antagonist activity at presynaptic glutamate receptors in neonatal rat spinal cord. Neuropharmacology 34:851-856.

Jane DE, Thomas NK, Tse HW, Watkins JC (1996) Potent antagonists at the L-AP-4- and (1S,3S)-ACPD-sensitive presynaptic metabotropic glutamate receptors in the neonatal rat spinal cord. Neuropharmacology 35:1029-1035.

Kingston AE, Ornstein PL, Wright RA, Johnson BG, Mayne NG, Burnett JP, Belagaje R, Wu S, Schoepp DD (1998) LY341495 is a nanomolar potent and selective antagonist of group II metabotropic glutamate receptors. Neuropharmacology 37:1-12.

Kogo N, Dalezios Y, Capogna M, Ferraguti F, Shigemoto R, Somogyi P (2004) Depression of GABAergic input to identified hippocampal neurons by group III metabotropic glutamate receptors in the rat. Eur J Neurosci 19:2727-2740.

Koschak A, Reimer D, Walter D, Hoda JC, Heinzle T, Grabner M, Striessnig J (2003) $\mathrm{Ca}_{\mathrm{v}} 1.4 \alpha 1$ subunits can form slowly inactivating dihydropyridinesensitive L-type $\mathrm{Ca}^{2+}$ channels lacking $\mathrm{Ca}^{2+}$-dependent inactivation. J Neurosci 23:6041-6049.

Koulen P, Brandstätter JH (2002) Pre- and postsynaptic site of action of mGluR8a in the mammalian retina. Invest Ophthalmol Vis Sci 43:1933-1940.

Koulen P, Kuhn R, Wässle H, Brandstätter JH (1999) Modulation of the intracellular calcium concentration in photoreceptor terminals by a pre- 
synaptic metabotropic glutamate receptor. Proc Natl Acad Sci USA 96:9909-9914.

Lasansky A (1973) Organization of the outer synaptic layer in the retina of the larval tiger salamander. Philos Trans R Soc Lond B Biol Sci 265:471-489.

Lasansky A (1978) Contacts between receptors and electrophysiologically identified neurones in the retina of the larval tiger salamander. J Physiol (Lond) 285:531-542.

Liu Y, Edwards RH (1997) The role of vesicular transport proteins in synaptic transmission and neural degeneration. Annu Rev Neurosci 20:125-156.

Maple BR, Gao F, Wu SM (1999) Glutamate receptors differ in rod- and cone-dominated off-center bipolar cells. NeuroReport 10:3605-3610.

Masu M, Iwakabe H, Tagawa Y, Miyoshi T, Yamashita M, Fukuda Y, Sasaki H, Hiroi K, Nakamura Y, Shigemoto R (1995) Specific deficit of the ON response in visual transmission by targeted disruption of the mGluR6 gene. Cell 80:757-765.

Matsui K, Hosoi N, Tachibana M (1998) Excitatory synaptic transmission in the inner retina: paired recordings of bipolar cells and neurons of the ganglion cell layer. J Neurosci 18:4500-4510.

Miller JL, Picones A, Korenbrot JI (1994) Differences in transduction between rod and cone photoreceptors: an exploration of the role of calcium homeostasis. Curr Opin Neurobiol 4:488-495.

Morgans CW (1999) Calcium channel heterogeneity among cone photoreceptors in the tree shrew retina. Eur J Neurosci 11:2989-2993.

Morgans CW (2001) Localization of the $\alpha_{1 \mathrm{~F}}$ calcium channel subunit in the rat retina. Invest Ophthalmol Vis Sci 42:2414-2418.

Nachman-Clewner M, St Jules R, Townes-Anderson E (1999) L-type calcium channels in the photoreceptor ribbon synapse: localization and role in plasticity. J Comp Neurol 415:1-16.

Nakanishi S (1994) Metabotropic glutamate receptors: synaptic transmission, modulation, and plasticity. Neuron 13:1031-1037.

Nakatani K, Yau KW (1988) Calcium and light adaptation in retinal rods and cones. Nature 334:69-71.

Nawy S (1999) The metabotropic receptor mGluR6 may signal through $G_{o}$, but not phosphodiesterase, in retinal bipolar cells. J Neurosci 19:2938-2944.

Nawy S (2004) Desensitization of the mGluR6 transduction current in tiger salamander On bipolar cells. J Physiol (Lond) 558:137-146.

Nawy S, Jahr CE (1990) Suppression by glutamate of cGMP-activated conductance in retinal bipolar cells. Nature 346:269-271.

Nawy S, Sie A, Copenhagen DR (1989) The glutamate analog 2-amino-4phosphonobutyrate antagonizes synaptic transmission from cones to horizontal cells in the goldfish retina. Proc Natl Acad Sci USA 86:1726-1730.

Nomura A, Shigemoto R, Nakamura Y, Okamoto N, Mizuno N, Nakanishi S (1994) Developmentally regulated postsynaptic localization of a metabotropic glutamate receptor in rat rod bipolar cells. Cell 77:361-369.

Palmer MJ, Hull C, Vigh J, von Gersdorff H (2003) Synaptic cleft acidification and modulation of short-term depression by exocytosed protons in retinal bipolar cells. J Neurosci 23:11332-11341.

Parsons TD, Sterling P (2003) Synaptic ribbon. Conveyor belt or safety belt? Neuron 37:379-382.

Rieke F, Schwartz EA (1994) A cGMP-gated current can control exocytosis at cone synapses. Neuron 13:863-873.

Rieke F, Schwartz EA (1996) Asynchronous transmitter release: control of exocytosis and endocytosis at the salamander rod synapse. J Physiol (Lond) 493:1-8.

Savchenko A, Barnes S, Kramer RH (1997) Cyclic-nucleotide-gated channels mediate synaptic feedback by nitric oxide. Nature 390:694-698.

Scanziani M, Gahwiler BH, Thompson SM (1995) Presynaptic inhibition of excitatory synaptic transmission by muscarinic and metabotropic glutamate receptor activation in the hippocampus: are $\mathrm{Ca}^{2+}$ channels involved? Neuropharmacology 34:1549-1557.

Schmitz Y, Witkovsky P (1996) Glutamate release by the intact lightresponsive photoreceptor layer of the Xenopus retina. J Neurosci Methods 68:55-60.

Schmitz Y, Witkovsky P (1997) Dependence of photoreceptor glutamate release on a dihydropyridine-sensitive calcium channel. Neuroscience 78:1209-1216.

Schnapf JL, Copenhagen DR (1982) Differences in the kinetics of rod and cone synaptic transmission. Nature 296:862-864.
Shen W, Slaughter MM (1998) Metabotropic and ionotropic glutamate receptors regulate calcium channel currents in salamander retinal ganglion cells. J Physiol (Lond) 510:815-828.

Shiells RA, Falk G, Naghshineh S (1981) Action of glutamate and aspartate analogues on rod horizontal and bipolar cells. Nature 294:592-594.

Slaughter MM, Miller RF (1981) 2-Amino-4-phosphonobutyric acid: a new pharmacological tool for retina research. Science 211:182-185.

Slaughter MM, Miller RF (1983) An excitatory amino acid antagonist blocks cone input to sign-conserving second-order retinal neurons. Science 219:1230-1232.

Stella SL, Thoreson WB (2000) Differential modulation of rod and cone calcium currents in tiger salamander retina by $\mathrm{D}_{2}$ dopamine receptors and cAMP. Eur J Neurosci 12:3537-3548.

Straiker A, Sullivan JM (2003) Cannabinoid receptor activation differentially modulates ion channels in photoreceptors of the tiger salamander. J Neurophysiol 89:2647-2654.

Takahashi T, Forsythe ID, Tsujimoto T, Barnes-Davies M, Onodera K (1996) Presynaptic calcium current modulation by a metabotropic glutamate receptor. Science 274:594-597.

Tang CM, Margulis M, Shi QY, Fielding A (1994) Saturation of postsynaptic glutamate receptors after quantal release of transmitter. Neuron 13:1385-1393.

Thoreson WB, Witkovsky P (1999) Glutamate receptors and circuits in the vertebrate retina. Prog Retin Eye Res 18:765-810.

Thoreson WB, Gottesman J, Jane DE, Tse HW, Watkins JC, Miller RF (1997) Two phenylglycine derivatives antagonize responses to L-AP-4 in ON bipolar cells of the amphibian retina. Neuropharmacology 36:13-20.

Thoreson WB, Tranchina D, Witkovsky P (2003) Kinetics of synaptic transfer from rods and cones to horizontal cells in the salamander retina. Neuroscience 122:785-798.

Vardi N, Duvoisin R, Wu G, Sterling P (2000) Localization of mGluR6 to dendrites of ON bipolar cells in primate retina. J Comp Neurol 423:402-412.

Verweij J, Kamermans M, Spekreijse H (1996) Horizontal cells feed back to cones by shifting the cone calcium-current activation range. Vision Res 36:3943-3953.

von Gersdorff H (2001) Synaptic ribbons: versatile signal transducers. Neuron 29:7-10.

von Gersdorff H, Schneggenburger R, Weis S, Neher E (1997) Presynaptic depression at a calyx synapse: the small contribution of metabotropic glutamate receptors. J Neurosci 17:8137-8146.

Wilkinson MF, Barnes S (1996) The dihydropyridine-sensitive calcium channel subtype in cone photoreceptors. J Gen Physiol 107:621-630.

Wright RA, Arnold MB, Wheeler WJ, Ornstein PL, Schoepp DD (2000) Binding of $\left[{ }^{3} \mathrm{H}\right]\left(2 S, 1^{\prime} S, 2^{\prime} S\right)-2$-(9-xanthylmethyl)-2-(2'-carboxycyclopropyl) glycine ([$\left.\left.{ }^{3} \mathrm{H}\right] \mathrm{LY} 341495\right)$ to cell membranes expressing recombinant human group III metabotropic glutamate receptor subtypes. Naunyn Schmiedebergs Arch Pharmacol 362:546-554.

Wu LG, Saggau P (1997) Presynaptic inhibition of elicited neurotransmitter release. Trends Neurosci 20:204-212.

Wu SM, Maple BR (1998) Amino acid neurotransmitters in the retina: a functional overview. Vision Res 38:1371-1384.

Wu SM, Gao F, Maple BR (2000) Functional architecture of synapses in the inner retina: segregation of visual signals by stratification of bipolar cell axon terminals. J Neurosci 20:4462-4470.

Xu HP, Zhao JW, Yang XL (2002) Expression of voltage-dependent calcium channel subunits in the rat retina. Neurosci Lett 329:297-300.

Yang XL, Wu SM (1996) Response sensitivity and voltage gain of the rodand cone-horizontal cell synapses in dark- and light-adapted tiger salamander retina. J Neurophysiol 76:3863-3874.

Yang XL, Wu SM (1997) Response sensitivity and voltage gain of the rodand cone-bipolar cell synapses in dark-adapted tiger salamander retina. J Neurophysiol 78:2662-2673.

Zamponi GW, Snutch TP (1998) Modulation of voltage-dependent calcium channels by $\mathrm{G}$ proteins. Curr Opin Neurobiol 8:351-356.

Zhang JF, Ellinor PT, Aldrich RW, Tsien RW (1996) Multiple structural elements in voltage-dependent $\mathrm{Ca}^{2+}$ channels support their inhibition by G proteins. Neuron 17:991-1003. 